Portland State University

PDXScholar

Civil and Environmental Engineering Master's

Project Reports

Civil and Environmental Engineering

Summer 8-18-2019

\title{
Water Quality Analysis of Ecoroof Runoff in Portland
}

Pranoti P. Deshmukh

Portland State University

Follow this and additional works at: https://pdxscholar.library.pdx.edu/cengin_gradprojects

Part of the Environmental Engineering Commons, and the Water Resource Management Commons Let us know how access to this document benefits you.

\section{Recommended Citation}

Deshmukh, Pranoti P., "Water Quality Analysis of Ecoroof Runoff in Portland" (2019). Civil and Environmental Engineering Master's Project Reports. 48.

https://doi.org/10.15760/CCEMP.47

This Project is brought to you for free and open access. It has been accepted for inclusion in Civil and Environmental Engineering Master's Project Reports by an authorized administrator of PDXScholar. Please contact us if we can make this document more accessible: pdxscholar@pdx.edu. 


\section{WATER QUALITY ANALYSIS OF ECOROOF RUNOFF IN PORTLAND}

By

\section{PRANOTI DESHMUKH}

A research project report submitted in partial fulfillment of the requirement for the degree of

MASTER OF SCIENCE

IN

CIVIL AND ENVIRONMENTAL ENGINEERING

Project Advisor:

Dr. William Fish

Portland State University

2019 
Water Quality Analysis of Ecoroof Runoff in Portland

\begin{abstract}
Portland, Oregon is internationally recognized for its implementation of sustainable stormwater management technologies. Ecoroof is one of the sustainable solutions to reduce stormwater runoff which also provides multiple environmental benefits. However, very little is known about the impact of ecoroofs on water quality of roof runoff. Stormwater runoff carries a significant amount of pollutants, which, if it directly enters a stream or river, degrades water quality and severely harms aquatic life.

This study evaluates the trends in the long-term water quality data from ecoroofs and conventional roofs in the Portland area. Mann Kendall trend test was used to detect the trends in concentrations of parameters. Concentration levels of metals (copper, lead, zinc) and nutrients (nitrogen and phosphorous) in runoff from ecoroofs were compared with the runoff from conventional roofs using Mann Whitney U test. Results indicated elevated levels of copper and phosphorous in ecoroof runoff. Concentrations of lead and zinc were found to be lower in ecoroof runoff than conventional roof runoff. Monitoring of ecoroof for a longer period is recommended for future studies to quantify the effect of roof age, thickness and composition of soil media, and plant types on runoff.
\end{abstract}


Water Quality Analysis of Ecoroof Runoff in Portland

\section{Acknowledgement}

This work would not have been possible without the contributions of many. Firstly, I would like to thank Dr. William Fish for giving me the wonderful opportunity to complete my project under his supervision.

I would like to express my sincere gratitude towards Stormwater Management Manual Team (SWMM) at Bureau of Environmental Service (BES), City of Portland. Special thanks to Adrienne Aiona, Alice Coker, Ivy Dunlap, Henry Stevens, Tim Kurtz for their constant encouragement and support. I especially express my warm thanks to Amy Simpson for her valuable time and mentorship. Also, I am grateful to Julia Bond for sharing her knowledge and expertise throughout this project.

I would like to thank my fellow graduate students who helped me get through two years of graduate school, Payal Joshi, Linely Mescher, Maysoun Hameed, Corina Overman, Tel Jenson, Amory Cervarich, Riyadh Muttaleb, and Bashar Al-Daomi. This journey could not have been more enjoyable without them. I am also thankful to kind staff of the Department of Civil and Environmental Engineering, Megan Falcone, Kiley Melicker, and Samantha Parsons who were always supportive and great resource.

I am fully indebted to my loving parents and in-laws for their love, patience, and support throughout my academic journey. I would like to thank Prachi, Sneha, Pushkarni, and Susmit for being a great source of happiness and joy to me during challenging times.

And finally, to my husband, Prabhanjan Wagh, who has been by my side throughout my graduate studies, living every single minute of it, and without whom, I would not have had the courage to embark on this journey in the first place. 
Water Quality Analysis of Ecoroof Runoff in Portland

\section{Table of Contents}

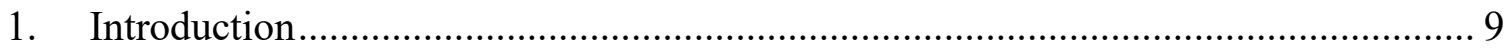

1.1 Green Infrastructure for Stormwater Management.......................................... 10

1.2 Ecoroof Overview and Pollution Concerns .....................................................11

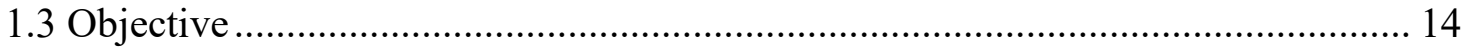

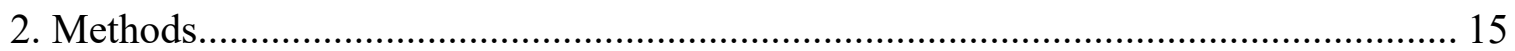

2.1 Site Descriptions ............................................................................... 15

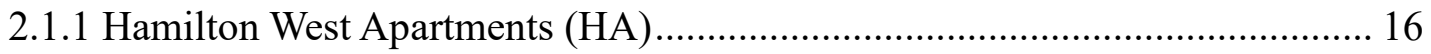

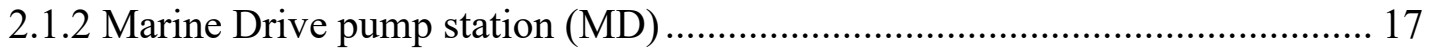

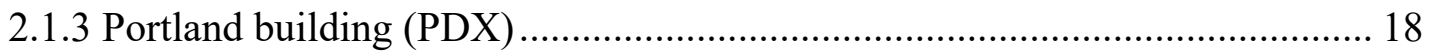

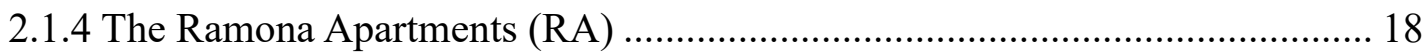

2.1.5 Sellwood Pump Station (SW) ............................................................. 19

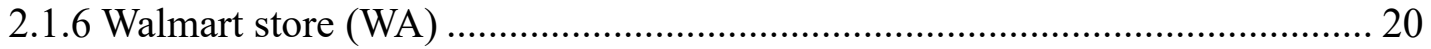

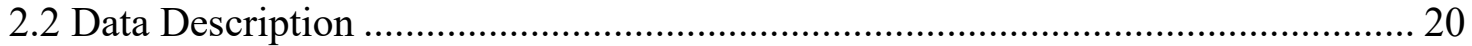

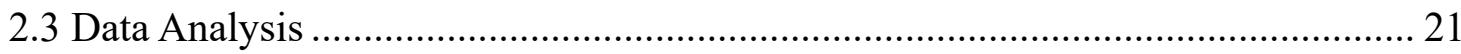

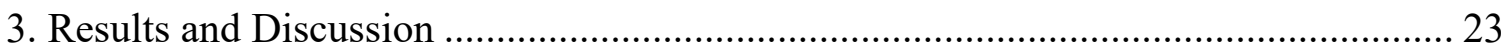

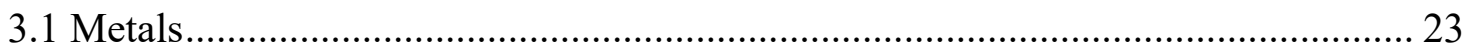

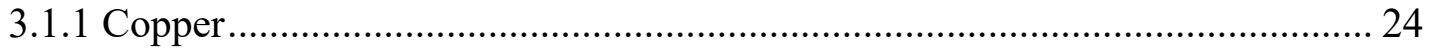

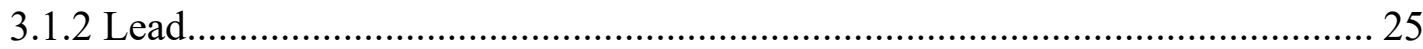

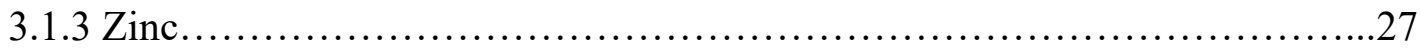


Water Quality Analysis of Ecoroof Runoff in Portland

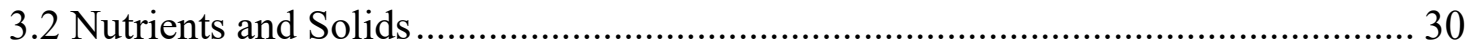

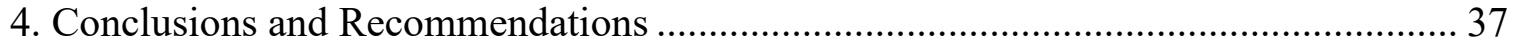

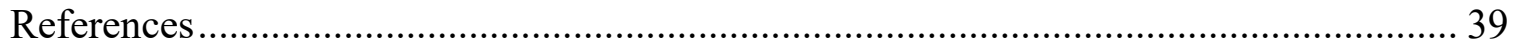

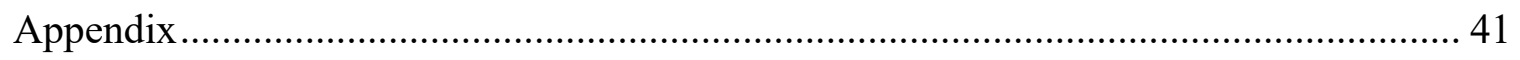


Water Quality Analysis of Ecoroof Runoff in Portland

\section{List of Figures}

Figure 1: Portland Sewer Systems, (BES, City of Portland) ................................................. 9

Figure 2: Ecoroof cross section (BES, City of Portland.) .......................................................11

Figure 3: Ecoroof Facilities: Portland (BES, City of Portland) ........................................... 12

Figure 4: Locations of the ecoroofs used in this study .................................................... 15

Figure 5: Hamilton ecoroof layout (BES, City of Portland) …......................................... 17

Figure 6: Marine Drive pump station ecoroof ............................................................. 17

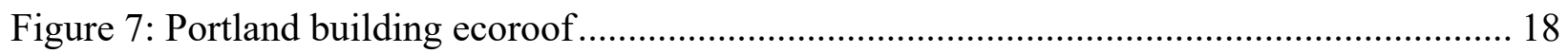

Figure 8: Ramona Apartment ecoroof.......................................................................... 19

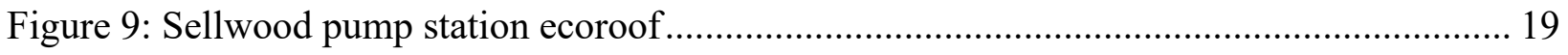

Figure 10: Walmart store ecoroof layout .......................................................................... 20

Figure 11: Boxplots showing total and dissolved $\mathrm{Cu}$ concentrations for all the sites. ............... 25

Figure 12: Boxplots showing total and dissolved $\mathrm{Pb}$ concentrations for all the sites ................. 27

Figure 13: Boxplots showing total and dissolved Zn concentrations for all the sites................. 29

Figure 14: Boxplots showing ammonia and nitrate concentrations for all the sites .................. 32

Figure 15: Boxplots showing o-phosphate and total phosphorous concentrations for all the sites

Figure 16: Boxplots showing total suspended solids concentrations for all the sites 34

Figure 17: Graphical representation of concentrations of $\mathrm{Cu}$ and $\mathrm{Cu}$ dissolved in ecoroof runoff

Figure 18: Graphical representation of Concentration of $\mathrm{Pb}$ and $\mathrm{Pb}$ dissolved in ecoroof runoff 45

Figure 19: Graphical representation of Concentration of $\mathrm{Zn}$ and $\mathrm{Zn}$ dissolved in ecoroof runoff 46 
Water Quality Analysis of Ecoroof Runoff in Portland

Figure 20:Graphical representation of Concentration of Ammonia and Nitrate in ecoroof runoff

Figure 21: Graphical representation of Concentration of o-Phosphate and TP in ecoroof runoff 48 
Water Quality Analysis of Ecoroof Runoff in Portland

\section{List of Tables}

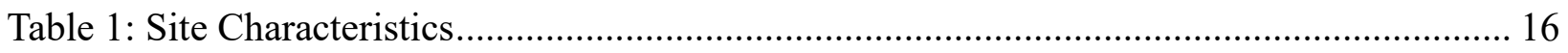

Table 2: Number of samples in monitoring period, 2001-2018 ........................................ 21

Table 3: Water quality parameters analyzed in this study with their abbreviations and units ...... 22

Table 4: Water quality standards for aquatic life in Oregon (Oregon DEQ, 2013) and the national

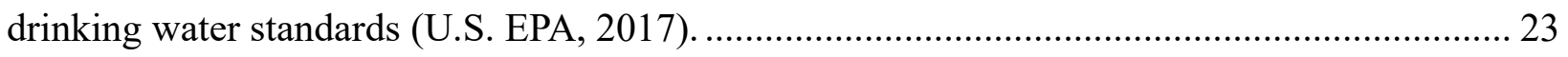

Table 5: Mean concentration of metals from ecoroof runoff for all sites ................................. 24

Table 6: Oregon water quality criteria for nutrients......................................................... 30

Table 7: Mean concentration of nutrients and TSS of ecoroof runoff for all sites.................... 31

Table 8: Results from MK trend test based on $\mathrm{p}$ and tau value ......................................... 35

Table 9: Results from Mann Whitney U Test................................................................ 36

Table 10: Summary Statistics for all water quality parameters in runoff ............................... 41

Table 11: Results from Mann Kendall Trend Test ........................................................... 49

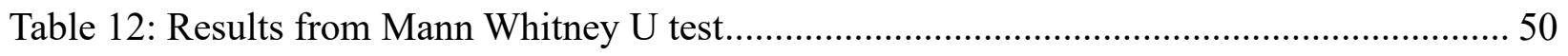




\section{Introduction}

Urban stormwater management presents a unique challenge worldwide because of continuously expanding urban impervious areas (Czemiel Berndtsson, 2010). Stormwater runoff picks up a wide variety of contaminants as it flows over the ground, rooftops, streets, and parking lots. Additionally, precipitation itself can contain a significant load of pollutants. Many larger and older cities, including Portland, have a combined sewer system to carry storm water and wastewater to treatment facilities (Figure 1). Excessive runoff can overburden Portland's combined storm sewers and wastewater treatment facilities, leading to combined sewer overflows (CSO) where untreated sewage and storm water is discharged to the Willamette River.

The City of Portland's Bureau of Environmental Services (BES) manages Portland's wastewater and storm water infrastructure and is responsible for watershed planning. BES provides wastewater and storm water collection and treatment services to the city, protecting human health and the quality of water in rivers and streams.

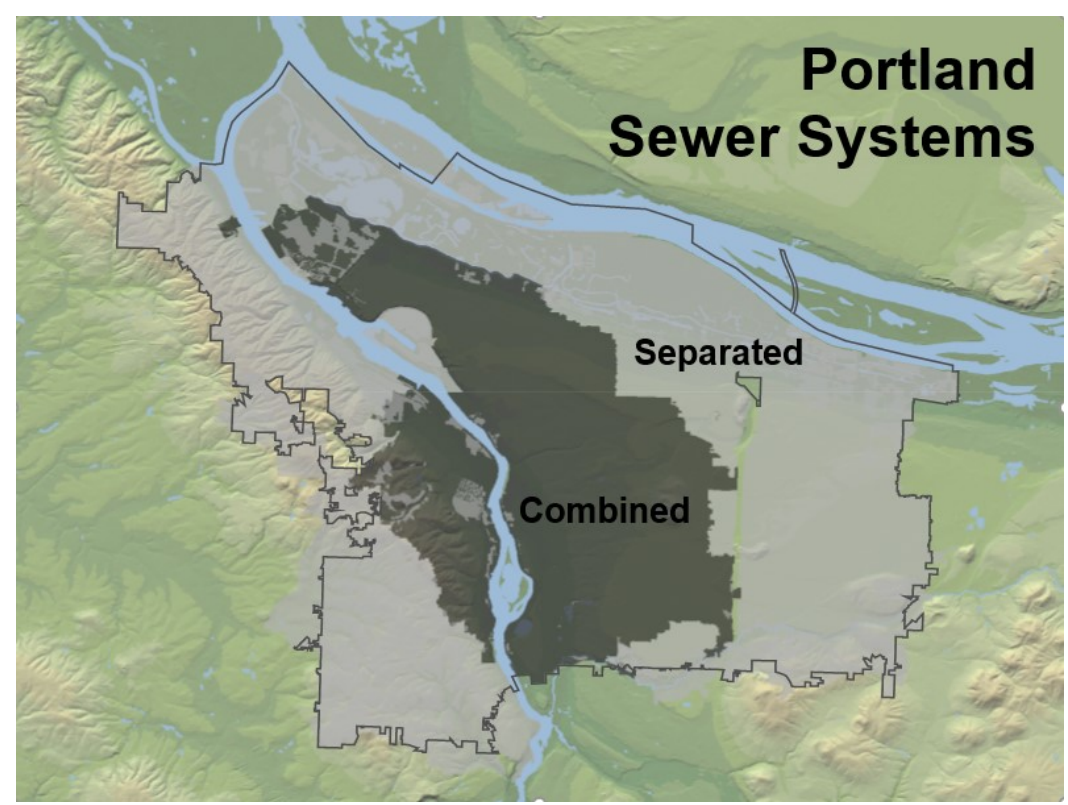

Figure 1: Portland Sewer Systems, (BES, City of Portland) 
Water Quality Analysis of Ecoroof Runoff in Portland

The City of Portland adopted a citywide Storm Water Management Manual (SWMM) in 1999 that includes water quality and flow control design standards for onsite storm water management facilities. Portland's SWMM gives priority to vegetated storm water management systems, low-impact development practices, and maintenance and operational best management practices (BMPs) designed to improve storm water quality.

BES monitors the performance of storm water management facilities around Portland. Gathering performance data on storm water management facilities and long-term monitoring helps in improving design, function, and lowering in maintenance cost.

\subsection{Green Infrastructure for Stormwater Management}

Portland's average annual rainfall of 37 inches generates approximately 10 billion gallons of storm water runoff. Green infrastructure comprises interconnected natural areas or engineered systems that use soil and plants to control, filter, and infiltrate runoff. Green infrastructure manages storm water runoff closer to the source by mimicking natural hydrology and provides multiple environmental benefits.

The City of Portland is a recognized leader in green and sustainable storm water management and promoting green infrastructure through various policies and incentive programs. Between 2008 and 2013, BES adopted a Grey to Green initiative to boost the city's green infrastructure. Portland's green infrastructure techniques are designed to address region's small and frequent storms. The City's Grey to green initiative includes award-wining BMP project designs, constructing green streets, ecoroofs, rain gardens, permeable pavements, bio-retention cells (or bio-swales), infiltration trenches, planter boxes, rooftop (downspout) disconnection, and urban tree canopies (BES, 2010). 


\subsection{Ecoroof Overview and Pollution Concerns}

With the increase in impervious area associated with urban development, there is a need of more sustainable urban drainage systems for attenuating runoff. Green roofs are one such a type of sustainable system to control urban runoff (Ferrans, Rey, Pérez, Rodríguez, \& Díaz-Granados, 2018) .

An ecoroof, or green roof, is the roof of a building, partially or fully covered with vegetated material along with waterproofing and a drainage system (Figure 2). An ecoroof decreases storm water runoff, helps to reduce urban heat island effect (Susca, Gaffin, \& Dell'Osso, 2011), improves air quality (Yang, Yu, \& Gong, 2008), and biodiversity. An ecoroof also saves energy (Spolek, 2008), absorbs $\mathrm{CO}_{2}$ and improves the aesthetics of the space.

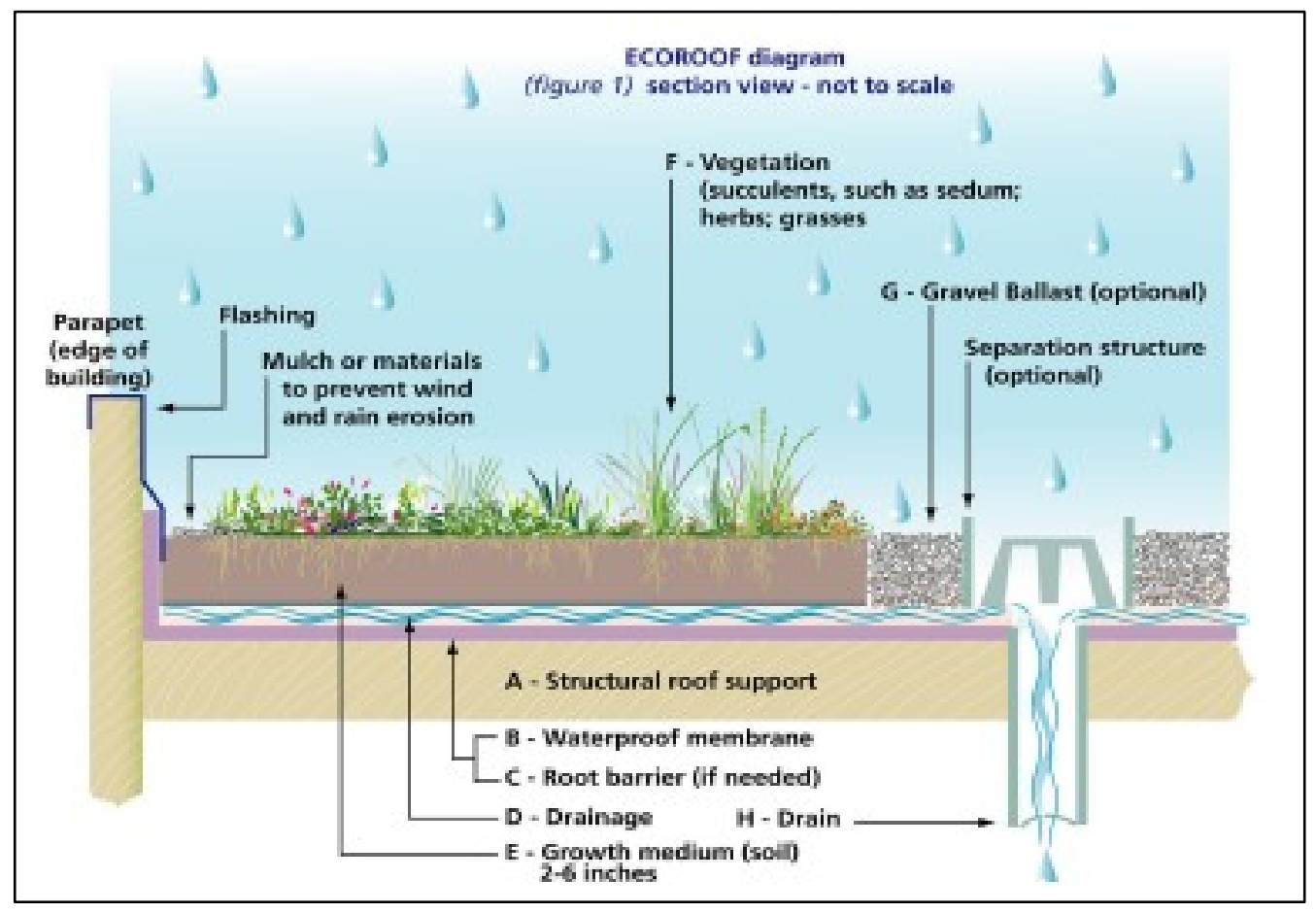

Figure 2: Ecoroof cross section (BES, City of Portland.)

An ecoroof is a best management practice for urban storm water management, however, more research is required to determine the impact of ecoroofs on the quality of roof runoff. 
Theoretically, vegetation on the ecoroof should absorb pollutants, but an ecoroof can also release pollutants depending upon the roofing material, the age of the roof, use of fertilizers, quality of precipitation, etc. (Li \& Babcock, 2014). Precipitation itself is a source of multiple contaminants (Sullivan, 2005).

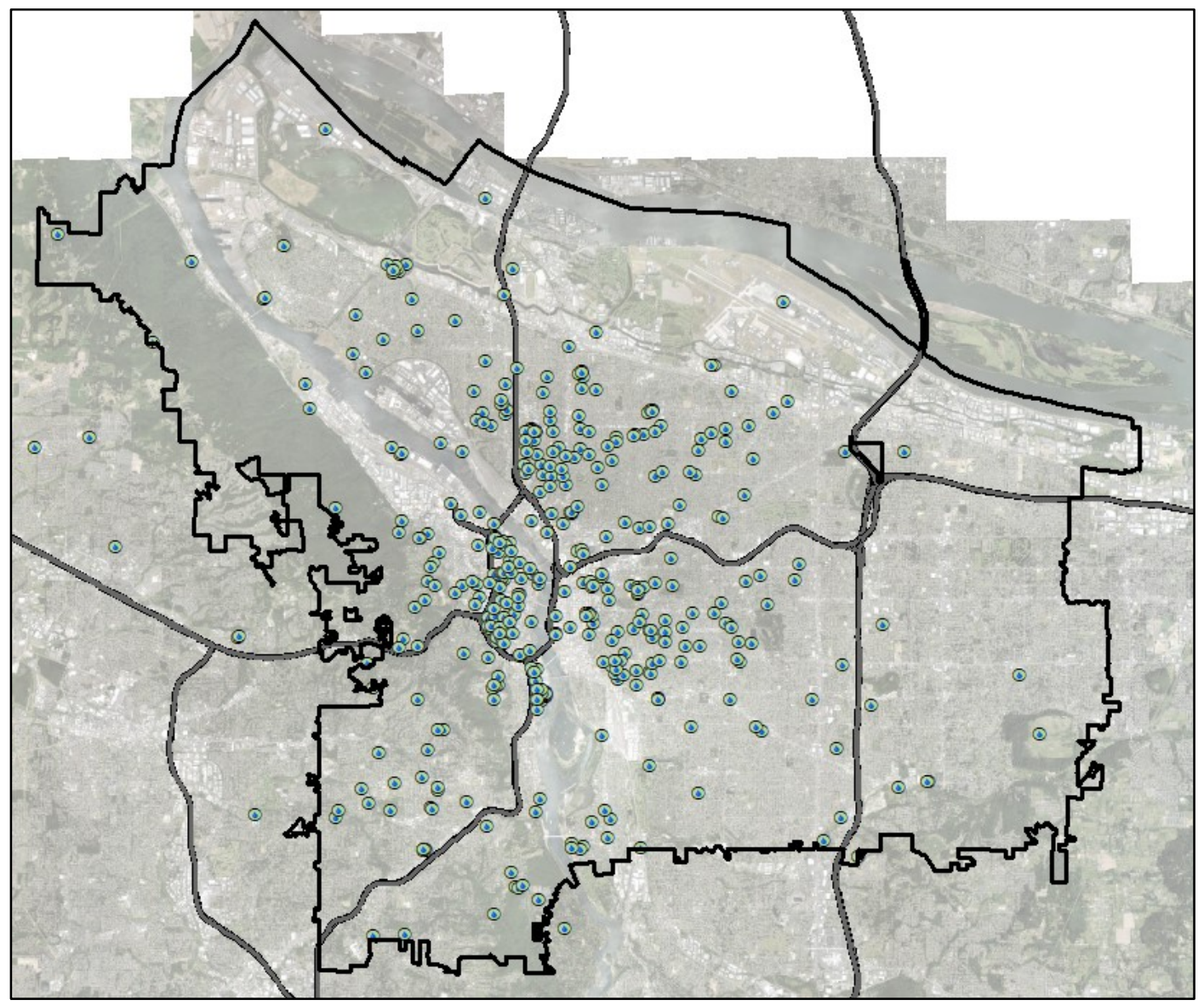

Figure 3: Ecoroof Facilities: Portland (BES, City of Portland)

Several studies have investigated the water quality of runoff from ecoroofs compared to the runoff from conventional roofs. Most of the studies examined concentration of nutrients (i.e., nitrogen and phosphorus) in the runoff and the findings indicate that ecoroofs are source of nutrients (Carpenter, Todorov, Driscoll, \& Montesdeoca, 2016; Mitchell, Matter, Durtsche, \& Buffam, 2017; Razzaghmanesh, Beecham, \& Myers, 2016; Teemusk, 2011). Primary sources of nutrients in green roof runoff are atmospheric deposition and leaching from the soil medium. A 
Water Quality Analysis of Ecoroof Runoff in Portland

few studies investigated metal concentration, however, and some found that runoff metal concentrations were higher than for conventional roof (Buffam, Mitchell, \& Durtsche, 2016; Gregoire \& Clausen, 2011). Elevated concentrations of heavy metals, such as $\mathrm{Cu}$ and Zn, in storm water runoff can be toxic to aquatic life. Cu concentrations as low as $2 \mu \mathrm{g} / \mathrm{L}$ can impact aquatic life (Sandahl et al. 2007). Elevated concentration of nutrients can lead to production of algal blooms in the receiving water body.

A study conducted in Lahti, Finland found higher concentrations of nitrate and total phosphorus in runoff from ecoroofs. However, bio char amendments in the growing media did decrease total nitrogen (TN) and total phosphorus (TP) load after one year of the experiment (Jokimaa, 2016). In a Swedish study, runoff from extensive sedum moss roofs and conventional roofs was measured for metals and nutrients (Berndtsson, Emilsson, \& Bengtsson, 2006). The results indicated that the ecoroofs studied were a source of pollutants, with the exception of nitrogen. A study carried out in North Carolina found that green roofs with high organic matter (e.g., compost) served as an additional source of TN and TP (Moran, Hunt, \& Jennings, 2004).

Approximately 38 acres of ecoroofs (over 560 roofs) have been installed on Portland buildings since the 1990s (Figure 3). Monitoring of ecoroofs in Portland by BES has previously shown that ecoroofs reduce peak flow and total runoff volumes compared to conventional roofs. However, little is known about ecoroof impact on water quality. Limited data collected from the City of Portland for one ecoroof has indicated that runoff from ecoroofs can have elevated concentrations of nutrients, mostly TN and TP (Hutchinson, et al , 2003). Cu concentrations were significantly higher than the concentration in conventional roof runoff (City of Portland BES, 2010). The City of Portland's Central City 2035 plan, which went into effect from July 2018, includes a requirement that all new structures $(>20,000 \mathrm{sq} . \mathrm{ft})$ constructed within the central city 
boundary should have $60 \%$ ecoroof coverage (Portland, 2018). With the expectation of new ecoroof installations, it is increasingly important to develop an improved understanding of the water quality of ecoroof runoff.

\subsection{Objective}

This study seeks to evaluate the trends in the long-term water quality data from ecoroofs in Portland area and provide recommendation for future monitoring plans. Six ecoroofs and two conventional roofs monitored by BES were studied.

Analysis of the results for each ecoroof facility will help to identify possible sources of contamination and will be used by BES to understand how soil media, age of the roof, and roofing material contribute to runoff water quality. 
Water Quality Analysis of Ecoroof Runoff in Portland

\section{Methods}

\subsection{Site Descriptions}

In 2001 BES began monitoring the water quality of various ecoroof facilities to determine the effect of ecoroofs on runoff water quality. Six different ecoroofs were selected for this analysis based on availability of water quality data. The ecoroofs evaluated in this study are located within the Portland city limits (Figure 4). A description of each ecoroof, including installation year, roof area, and soil media depth is included in Table 1.

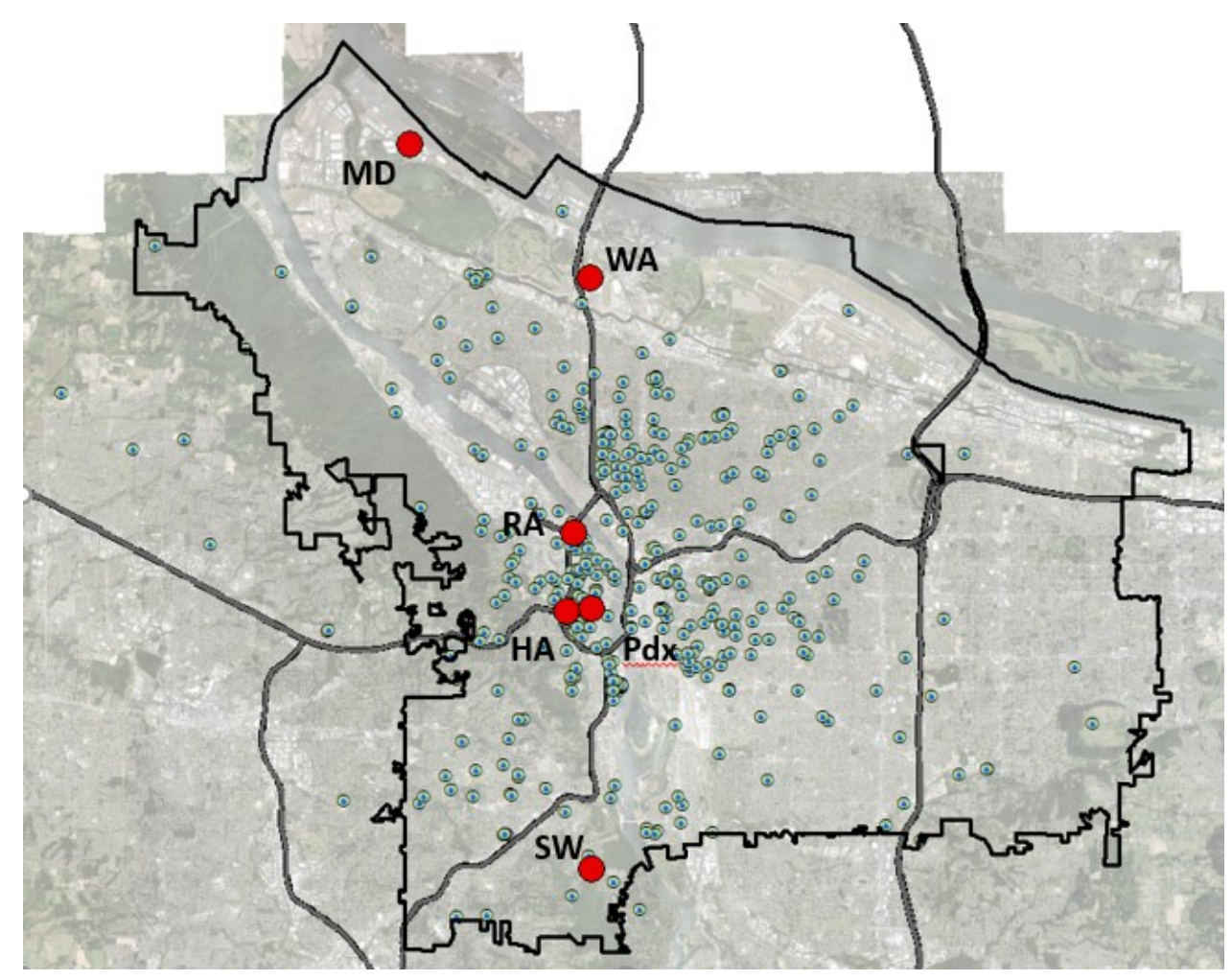

Figure 4: Locations of the ecoroofs used in this study 
Table 1: Site Characteristics

\begin{tabular}{|c|c|c|c|c|c|}
\hline Site & $\begin{array}{c}\text { Installation } \\
\text { year }\end{array}$ & $\begin{array}{l}\text { Ecoroof } \\
(\mathrm{sq} \cdot \mathrm{ft})\end{array}$ & $\begin{array}{l}\text { Drainage } \\
\text { area (sq. } \\
\quad \mathrm{ft})\end{array}$ & $\begin{array}{l}\text { Soil } \\
\text { Depth } \\
\text { (in) }\end{array}$ & Soil Media \\
\hline $\begin{array}{c}\text { HA } \\
\text { East }\end{array}$ & 1999 & 2520 & 3811 & 3 & $\begin{array}{c}25 \% \text { encapsulated } \\
\text { polystyrene, } 15 \% \\
\text { digested fiber, } 15 \% \text { coir } \\
\text { fiber, } 15 \% \text { perlite, } 15 \% \\
\text { peat moss, } 15 \% \text { compost }\end{array}$ \\
\hline $\begin{array}{c}\text { HA } \\
\text { West }\end{array}$ & 1999 & 2620 & 3655 & 5 & $\begin{array}{c}28 \% \text { sandy loam, } 22 \% \\
\text { perlite, } 20 \% \text { digested } \\
\text { fiber, } 20 \% \text { coir fiber, } \\
10 \% \text { compost }\end{array}$ \\
\hline PDX & 2006 & 16000 & 5250 & 5 & 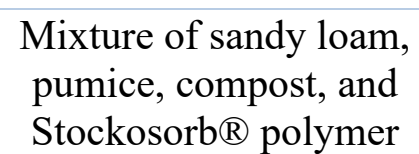 \\
\hline MD & 2012 & 288 & $* *$ & 5 & $\begin{array}{l}\text { Mixture of sandy loam, } \\
\text { soil life compost, fiber } \\
\text { life compost and pumice }\end{array}$ \\
\hline RA & 2012 & 32000 & $* *$ & 3.5 & $\begin{array}{l}70 \% \text { Pumice and } 30 \% \\
\text { organic materials }\end{array}$ \\
\hline SW & 2012 & 2200 & $* *$ & 5 & $\begin{array}{l}\text { Mixture of sandy loam, } \\
\text { soil life compost, fiber } \\
\text { life compost and pumice }\end{array}$ \\
\hline WA & 2013 & 54000 & $\begin{array}{l}12915 \\
12915\end{array}$ & $\begin{array}{l}5 \\
3\end{array}$ & $\begin{array}{l}\text { Mixture of sandy loam, } \\
\text { pumice, and compost }\end{array}$ \\
\hline
\end{tabular}

2.1.1 Hamilton West Apartments (HA): Hamilton West is a nine-story apartment building with 152 homes. The ecoroof on Hamilton apartments was installed in the Fall of 1999 and has been monitored since 2001. To test stormwater capacity of different types of soil, the ecoroof was divided into east and west drainage areas with different soil media and separate roof drains (Figure 5). The east side was installed with three inches of lightweight material while the west side with five inches of heavier material. To prevent soil loss due to wind, red pumice was added to the east side. 


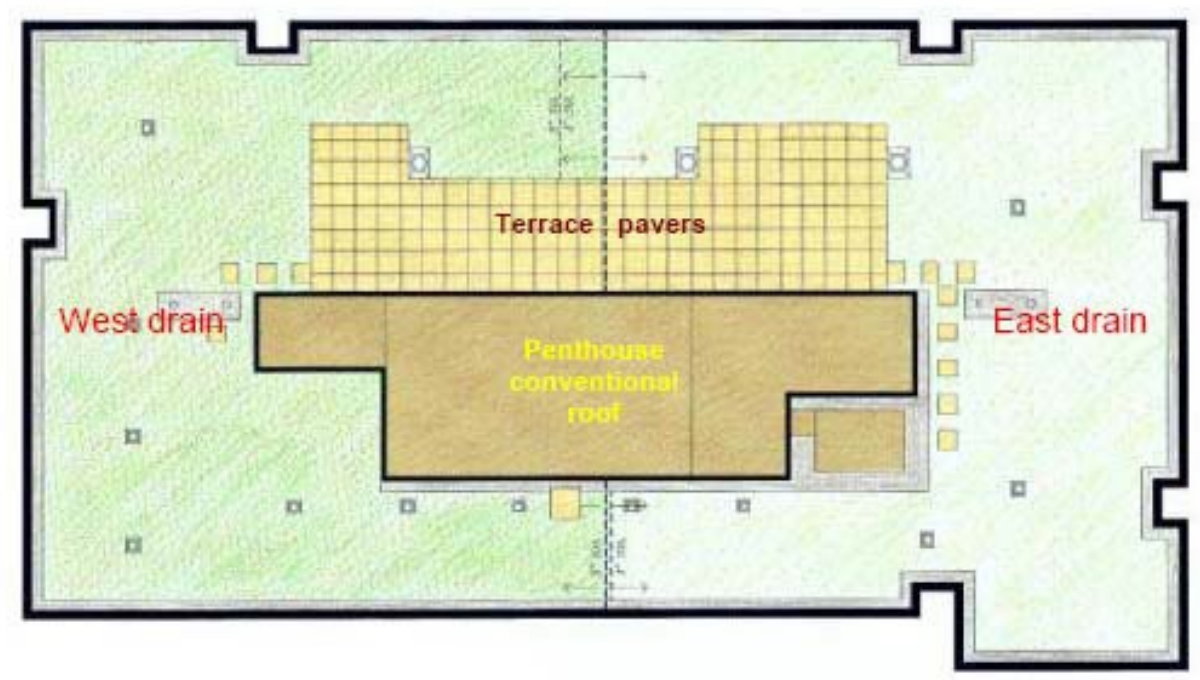

Figure 5: Hamilton ecoroof layout (BES, City of Portland)

This ecoroof was planted with 75 species of succulents and grasses. The Hamilton ecoroof receives precipitation and runoff from stone terrace.

2.1.2 Marine Drive pump station (MD): The ecoroof on the Marine Drive pump station was installed in 2012 and was monitored until 2014. A five-inch deep growing medium consisting of a mixture of sandy loam, soil life compost, fiber life compost and pumice ('Pro Gro Semi Intensive Media') was used (Figure 6).

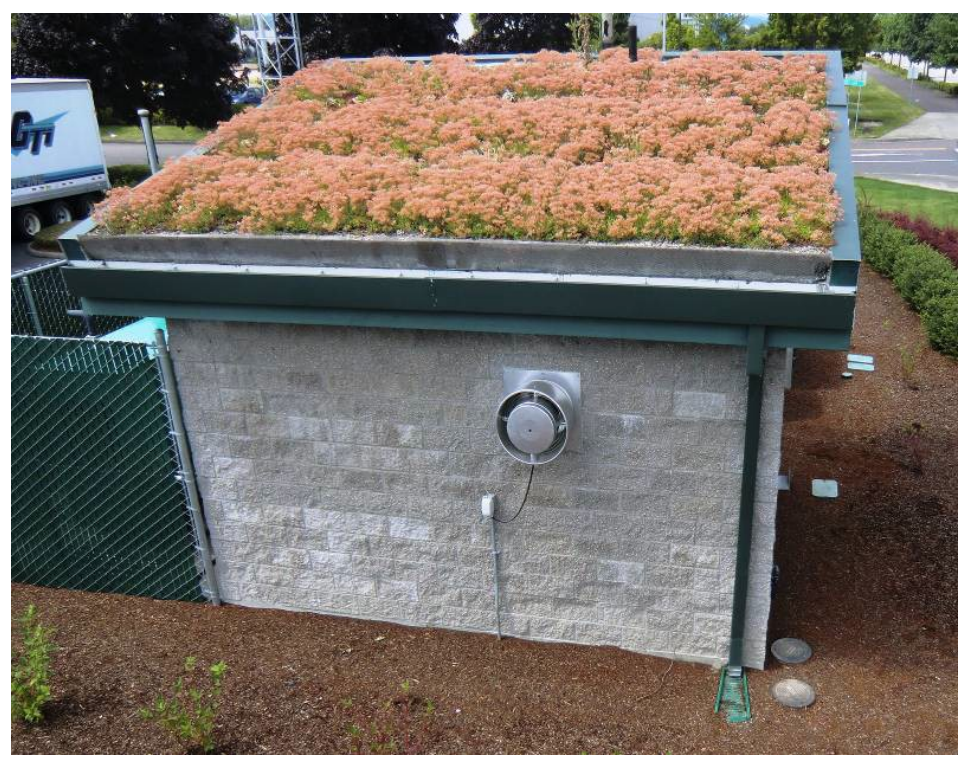

Figure 6: Marine Drive pump station ecoroof 
2.1.3 Portland building (PDX): The Portland Building is a 15-story municipal office building in downtown Portland. The roof of the Portland Building was retrofitted in the summer of 2006 with a new ecoroof (approximately 5250 sq. $\mathrm{ft}$ ) The Portland Building ecoroof was monitored from March 2007 to Jun 2012. Three inches of soil media was used with a proprietary mix of sandy loam, pumice, compost, and Stockosorb ${ }^{\circledR}$ Polymer (Figure 7).

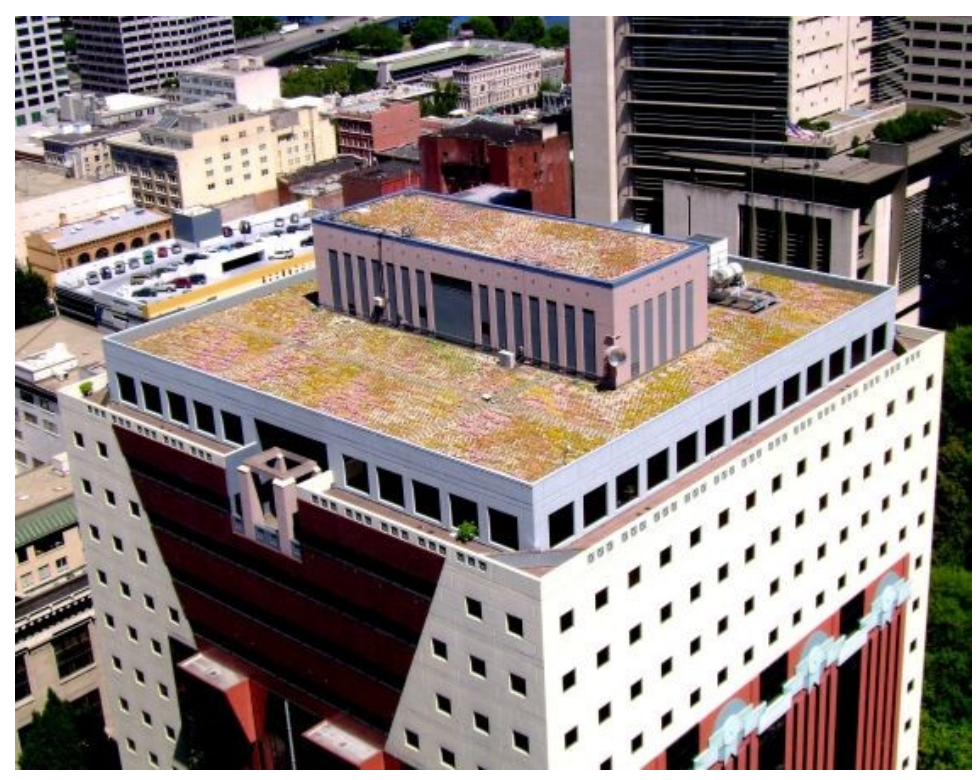

Figure 7: Portland building ecoroof

2.1.4 The Ramona Apartments (RA): The Ramona is a 6-story apartment building with 138 homes. A 32,000 sq. ft ecoroof was installed on The Ramona Apartments in 2011. A 3.5" deep soil mix was used, which consisted of roughly $70 \%$ pumice and $30 \%$ organic material. 26 species of succulents and grasses were planted (Figure 8). 
Water Quality Analysis of Ecoroof Runoff in Portland

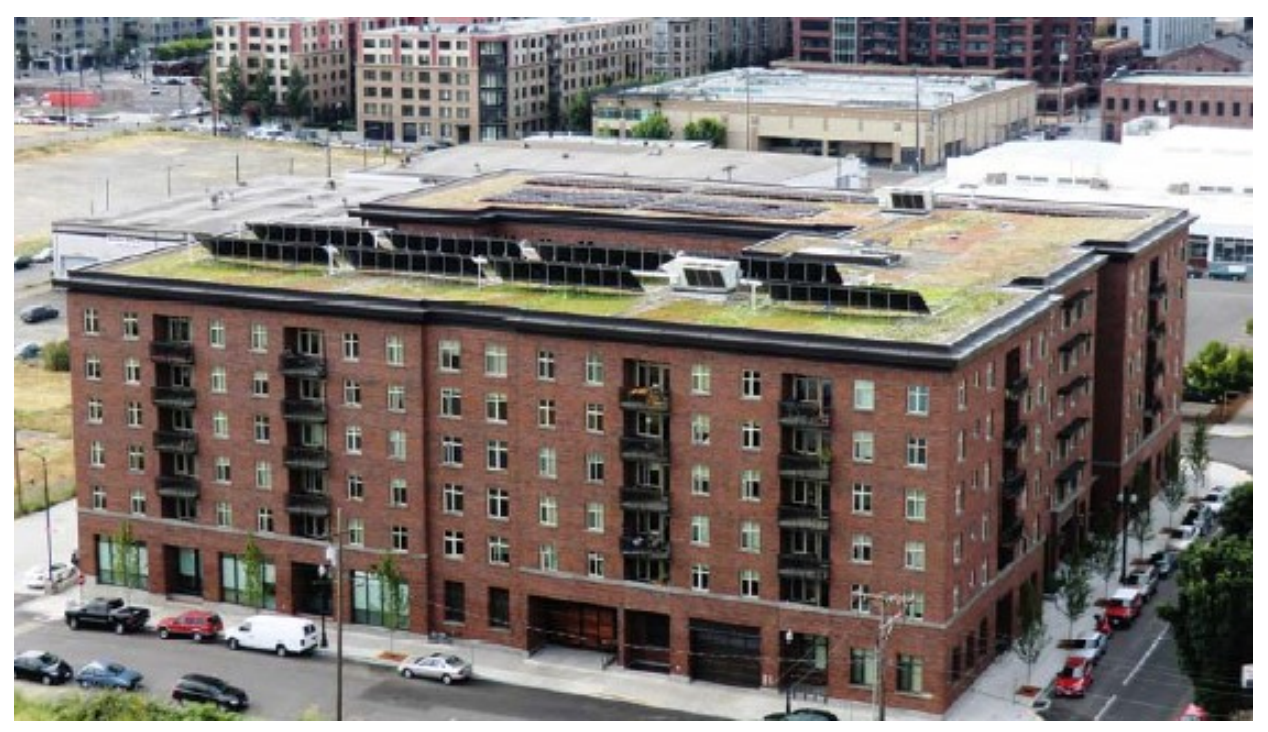

Figure 8: Ramona Apartment ecoroof

2.1.5 Sellwood Pump Station (SW): An ecoroof on the Sellwood pump station was installed in 2012 and was monitored until 2014. A five-inch growing medium consists of Gro Pro semi intensive mixture was used (Figure 9) and succulents and grasses were planted.

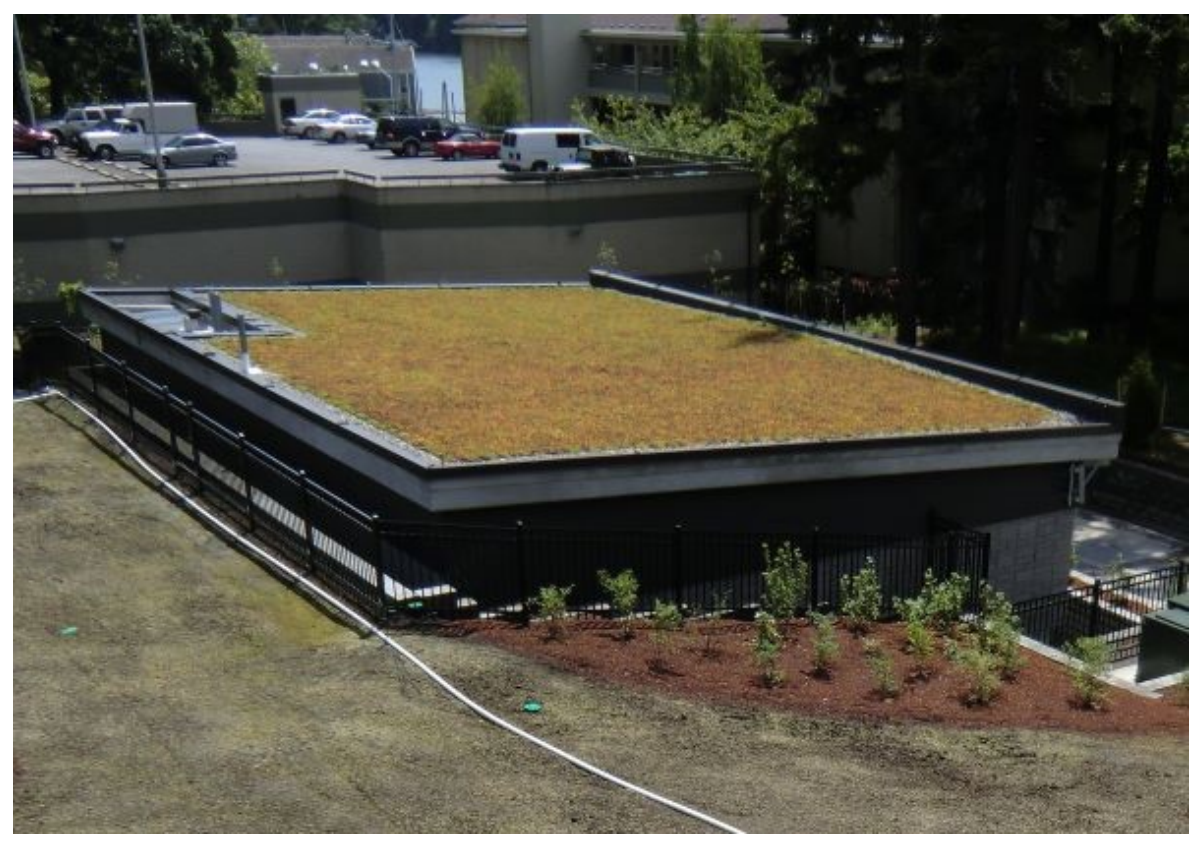

Figure 9: Sellwood pump station ecoroof 
2.1.6 Walmart store (WA): An ecoroof on a Walmart store was installed in 2013. The ecoroof was divided into three equal 12915 sq.ft sections of different media depths next to an impermeable 15,800 sq.ft conventional roof (Figure 10). WA 5 denotes ecoroof with a fiveinch soil media while WA 3 denotes ecoroof with three-inch soil media. Mixture of pumice, compost, and sandy loam was used on both ecoroof sections. Succulents and grasses were planted on ecoroofs.

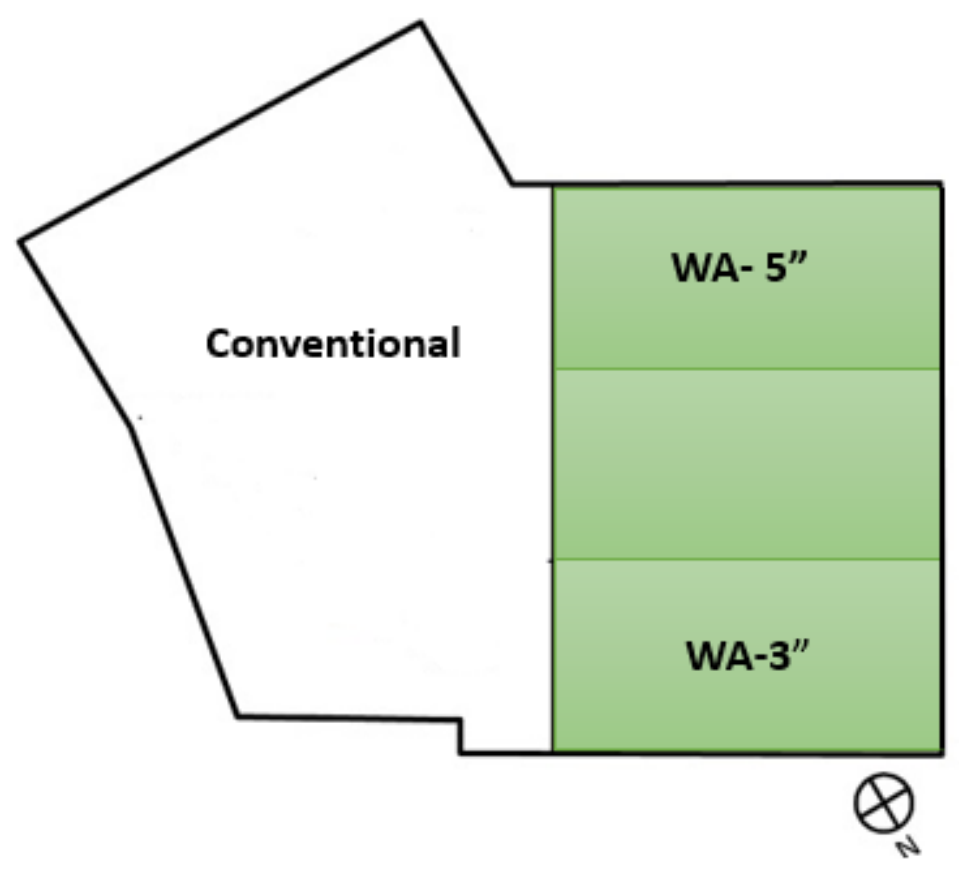

Figure 10: Walmart store ecoroof layout

\subsection{Data Description}

Sampling was conducted by BES Field Operations Staff to analyze for various parameters from ecoroof runoff. Grab samples were collected by placing a decontaminated stainless-steel beaker or the analyte specific sample containers under the flow discharging from the flumes (City of Portland BES, 2010). To compare ecoroof performance with conventional roof, runoff samples from conventional roofs of HA and WA were also collected. Due to technical issues monitoring 
Water Quality Analysis of Ecoroof Runoff in Portland

equipment from east side of HA was removed in 2008. A detailed description of monitoring periods and the collected number of samples is included in Table 2. In this study, a total of 117 samples were analyzed by descriptive and analytical statistics.

Table 2: Number of samples in monitoring period, 2001-2018

\begin{tabular}{|l|l|l|}
\hline Site & Monitoring Period & No of Samples \\
\hline HA East & $2001-2008$ & 15 \\
\hline HA West & $2001-2018$ & 31 \\
\hline HA Conventional & $2002-2018$ & 18 \\
\hline MD & $2012-2014$ & 6 \\
\hline PDX & $2007-2012$ & 14 \\
\hline RA & $2012-2014$ & 4 \\
\hline SW & $2012-2014$ & 4 \\
\hline WA 5 & $2014-2018$ & 8 \\
\hline WA 3 & $2014-2018$ & 8 \\
\hline WA Conventional & $2014-2018$ & 9 \\
\hline
\end{tabular}

\subsection{Data Analysis}

The water quality data from six ecoroof sites in Portland were analyzed. The analyzed water quality parameters included arsenic, copper, chromium, lead, zinc, conductivity, E.coli, hardness, ammonia, nitrate, orthophosphate, total phosphorus, solids. In this study water quality parameters of concern in the Portland area, metals (copper, zinc, lead), nutrients (phosphorus and nitrogen) and total suspended solids which can have potentially adverse impact on human health or aquatic organisms were analyzed statistically (Table 3). Orthophosphate $\left(\mathrm{PO}_{4}^{-3}\right)$ is a biologically highly available form of soluble phosphorus readily used by plants. Total phosphorus (TP) is a measurement of all phosphorus species, including polyphosphates and organic forms. 
Water Quality Analysis of Ecoroof Runoff in Portland

Table 3: Water quality parameters analyzed in this study with their abbreviations and units

\begin{tabular}{|l|l|l|}
\hline Parameters & Abbreviations & Units \\
\hline Copper & $\mathrm{Cu}$ & $\mu \mathrm{g} / \mathrm{L}$ \\
\hline Dissolved copper & $\mathrm{Dissolved} \mathrm{Cu}$ & $\mu \mathrm{g} / \mathrm{L}$ \\
\hline Lead & $\mathrm{Pb}$ & $\mu \mathrm{g} / \mathrm{L}$ \\
\hline Dissolved lead & Dissolved $\mathrm{Pb}$ & $\mu \mathrm{g} / \mathrm{L}$ \\
\hline Zinc & $\mathrm{Zn}$ & $\mu \mathrm{g} / \mathrm{L}$ \\
\hline Dissolved zinc & $\mathrm{Dissolved} \mathrm{Zn}$ & $\mu \mathrm{g} / \mathrm{L}$ \\
\hline Ammonium nitrate & $\mathrm{NH}_{4}-\mathrm{N}$ & $\mathrm{mg} / \mathrm{L}$ \\
\hline Nitrate nitrogen & $\mathrm{NO}_{3}-\mathrm{N}$ & $\mathrm{mg} / \mathrm{L}$ \\
\hline Orthophosphate & $\mathrm{PO}_{4}^{-3}$ & $\mathrm{mg} / \mathrm{L}$ \\
\hline Total phosphorus & $\mathrm{TP}^{-3}$ & $\mathrm{mg} / \mathrm{L}$ \\
\hline Total suspended solids & $\mathrm{TSS}$ & $\mathrm{mg} / \mathrm{L}$ \\
\hline
\end{tabular}

Statistical analyses were carried out using R programming software (version 3.4.3). To present summary statistics (min, mean, median, max) of all parameters, data were first analyzed using descriptive analysis. To detect the existence of trends in the data, the Mann Kendall (MK) trend test was used. This test showed whether concentration values for parameter increased, decreased or were statistically trendless over time.

The data of ecoroof runoff from all sites were graphically analyzed before performing MK trend test. Box plots and scatter plots were used for exploratory data analysis. The null hypothesis $\left(\mathrm{H}_{\mathrm{o}}\right)$ for the MK trend test was that there is no trend present in the data. That is, data obtained over time were identically distributed and not correlated over time. The alternative hypothesis $\left(\mathrm{H}_{\mathrm{a}}\right)$ was that there is a trend present in the data.

To compare the data of conventional roof and ecoroof runoff from WA and HA, nonparametric Mann Whitney $U$ test was carried out. The null hypothesis for this test was that the concentration distribution from the two roof types were equal. 


\section{Results and Discussion}

A statistical summary of the concentrations of all parameters from ecoroof runoff are presented in the Appendix (Table 10). Graphical results for the concentrations over time for the studied parameters are included in the appendix (Figure 17- Figure 20). Results from Mann Kendall trend test and Mann Whitney U test are included in Table 8 and Table 9 respectively.

\subsection{Metals}

A statistical summary of concentrations of metals on all sites is given in the Appendix (Table 10) and mean values for total and dissolved $\mathrm{Cu}, \mathrm{Pb}$ and $\mathrm{Zn}$ are presented in Table 5. As there are no standards for water quality of roof runoff, results were only compared with water quality standards in streams.

Table 4: Water quality standards for aquatic life in Oregon (Oregon DEQ, 2013) and the national drinking water standards (U.S. EPA, 2017).

\begin{tabular}{llll}
\hline Parameters $(\boldsymbol{\mu g} / \mathbf{L})$ & $\mathbf{C u}$ & $\mathbf{P b}$ & $\mathbf{Z n}$ \\
\hline Aquatic Life Chronic Criteria & $2-4^{*}$ & $0.5^{* *}$ & $36^{* *}$ \\
Drinking Water Standards & 1300 & 15 & $\mathrm{n} / \mathrm{a}$ \\
\hline
\end{tabular}

* The freshwater criterion for copper is a function of the concentration of ions, alkalinity, organic carbon, $\mathrm{pH}$ and temperature, and is calculated using the Biotic Ligand Model. For purposes of illustration, a limit calculated using default values is included.

** The freshwater criterion for lead and zinc is calculated as a function of hardness. For the purposes of illustration, limits calculated using default values are included. 
Water Quality Analysis of Ecoroof Runoff in Portland

Table 5: Mean concentration of metals from ecoroof runoff for all sites

\begin{tabular}{|c|c|c|c|c|c|c|c|c|c|c|}
\hline \multirow{2}{*}{$\begin{array}{r}\text { Parameters } \\
(\mu \mathrm{g} / \mathrm{L})\end{array}$} & \multicolumn{10}{|c|}{ Sites } \\
\hline & $\begin{array}{r}\text { HA } \\
\text { East }\end{array}$ & $\begin{array}{r}\text { HA } \\
\text { West }\end{array}$ & $\begin{array}{r}\text { HA } \\
\text { Conv }\end{array}$ & MD & PDX & RA & SW & $\begin{array}{r}\text { WA } \\
5\end{array}$ & $\begin{array}{r}\text { WA } \\
\mathbf{3}\end{array}$ & $\begin{array}{r}\text { WA } \\
\text { Conv }\end{array}$ \\
\hline $\mathbf{C u}$ & 8.98 & 11.80 & 2.6 & 18.93 & 11.4 & 10.31 & 7.7 & 5.93 & 6.02 & 1.34 \\
\hline Dissolved Cu & 7.28 & 10.35 & 1.9 & 16.16 & 10.07 & 9.38 & 7.6 & 5.55 & 5.59 & 0.45 \\
\hline $\mathbf{P b}$ & 2.86 & 0.45 & 0.35 & 0.22 & 2.09 & 0.16 & 0.1 & 0.19 & 0.16 & 0.21 \\
\hline Dissolved Pb & 1.28 & 0.44 & 0.10 & 0.17 & 0.65 & 0.1 & 0.1 & 0.10 & 0.1 & 0.1 \\
\hline Zn & 55.85 & 20.7 & 335.2 & 62.6 & 17.99 & 7.24 & 191 & 19.5 & 19.0 & 40.9 \\
\hline Dissolved Zn & 49.8 & 17.7 & 305.9 & 56.32 & 15.57 & 5.21 & 17.1 & 16.9 & 15.8 & 35.1 \\
\hline
\end{tabular}

3.1.1 Copper $(\mathbf{C u})$ : The $\mathrm{Cu}$ concentrations in ecoroof runoff were generally higher initially but then decreased over time. The concentration of dissolved $\mathrm{Cu}$ was slightly higher on the HA west ecoroof than HA east and ranged from $0.5 \mu \mathrm{g} / \mathrm{L}$ to $26.3 \mu \mathrm{g} / \mathrm{L}$ (Appendix; Table 10). The average dissolved $\mathrm{Cu}$ concentration on east and west side ecoroofs was much higher than conventional roof (average of $2.6 \mu \mathrm{g} / \mathrm{L}$ total; $1.9 \mu \mathrm{g} / \mathrm{L}$ dissolved). Similarly, average concentration on conventional roof of site WA $(1.34 \mu \mathrm{g} / \mathrm{L}$ total; $0.45 \mu \mathrm{g} / \mathrm{L}$ dissolved) was lower than ecoroofs on WA 5 and WA 3. All other sites had similar concentration of average $\mathrm{Cu}$ concentration though slightly higher on $\mathrm{MD}(18.9 \mu \mathrm{g} / \mathrm{L}$ total; $16.16 \mu \mathrm{g} / \mathrm{L}$ dissolved). Total $\mathrm{Cu}$ concentration ranged from $4.08 \mu \mathrm{g} / \mathrm{L}$ to 72.8 $\mu \mathrm{g} / \mathrm{L}$ while dissolved $\mathrm{Cu}$ from $3.64 \mu \mathrm{g} / \mathrm{L}$ to $59.4 \mu \mathrm{g} / \mathrm{L}$. Boxplots for concentration of $\mathrm{Cu}$ are presented in figure 11. For comparison, the mean $\mathrm{Cu}$ concentration standard for aquatic life in Oregon is $2-4 \mu \mathrm{g} / \mathrm{L}$ in stream (Table 4 ).

Results from MK test showed no trend for $\mathrm{Cu}$ concentration except for the PDX site, where based on $\mathrm{p}$ and tau values, decreasing trend was observed (Table 8). Using Mann Whitney U test, 
significant differences were found in $\mathrm{Cu}$ concentrations at conventional roof and ecoroofs sites ( $\mathrm{p}$ value $<0.05$ ) on both HA and WA site (Table 9).
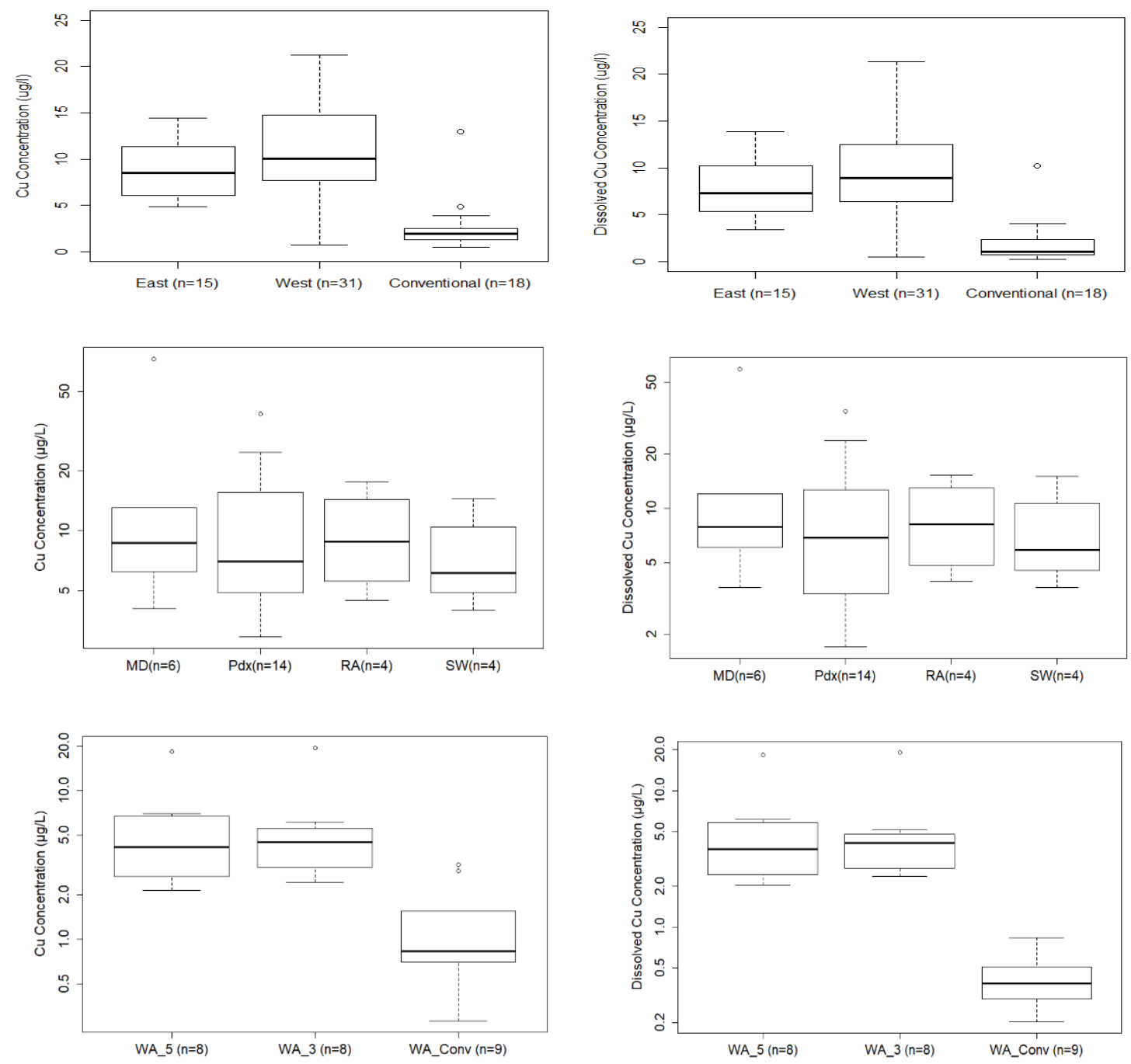

Figure 11: Boxplots showing total and dissolved Cu concentrations for all the sites.

Graphical representation for HA showed variable concentration of $\mathrm{Cu}$ however, all other sites showed downward trend of concentration over time (Appendix; Figure 17).

3.1.2 Lead: The average concentration levels of $\mathrm{Pb}$ were much lower on the HA west ecoroof $(0.45 \mu \mathrm{g} / \mathrm{L}$ total; $0.44 \mu \mathrm{g} / \mathrm{L}$ dissolved $)$ than HA east side $(2.86 \mu \mathrm{g} / \mathrm{L}$ total; $1.89 \mu \mathrm{g} / \mathrm{L}$ dissolved $)$. 
Total $\mathrm{Pb}$ concentration on $\mathrm{HA}$ east ranged from $0.16 \mu \mathrm{g} / \mathrm{L}$ to $23.5 \mu \mathrm{g} / \mathrm{L}$ and that of $\mathrm{HA}$ west from $0.1 \mu \mathrm{g} / \mathrm{L}$ to $5.12 \mu \mathrm{g} / \mathrm{L}$. Maximum dissolved $\mathrm{Pb}$ concentration on HA east was $13.6 \mu \mathrm{g} / \mathrm{L}$ versus $1.02 \mu \mathrm{g} / \mathrm{L}$ in $\mathrm{HA}$ west. The east side media contains higher amount of $\mathrm{Pb}$ than media on west side which could be the source of higher concentration of $\mathrm{Pb}$ on east side. The concentration levels on both HA west and HA east ecoroof were higher than a conventional roof. All other sites including WA showed lower concentration of $\mathrm{Pb}$ (ranged from $0.1 \mu \mathrm{g} / \mathrm{L}$ to $0.6 \mu \mathrm{g} / \mathrm{L}$ ) except on PDX where average total $\mathrm{Pb}$ concentration was slightly higher $(2.09 \mu \mathrm{g} / \mathrm{L})$. Boxplots for the concentration of $\mathrm{Pb}$ are presented in figure 12. Thus, mean $\mathrm{Pb}$ concentration was higher than Oregon water quality standards for aquatic life in stream for HA east and PDX sites (Table 4). Results from all other sites indicated $\mathrm{Pb}$ concentration below that water quality benchmark.

Results from MK test showed a decreasing concentration trend on HA west site but increasing trend on HA east and WA 3 (Table 8). HA east and WA3 both ecoroofs have soil media depth of 3 inches. No trend detected on other remaining sites. Results from Mann Whitney U test showed significant difference in only HA east and HA conventional roof (Table 9). 

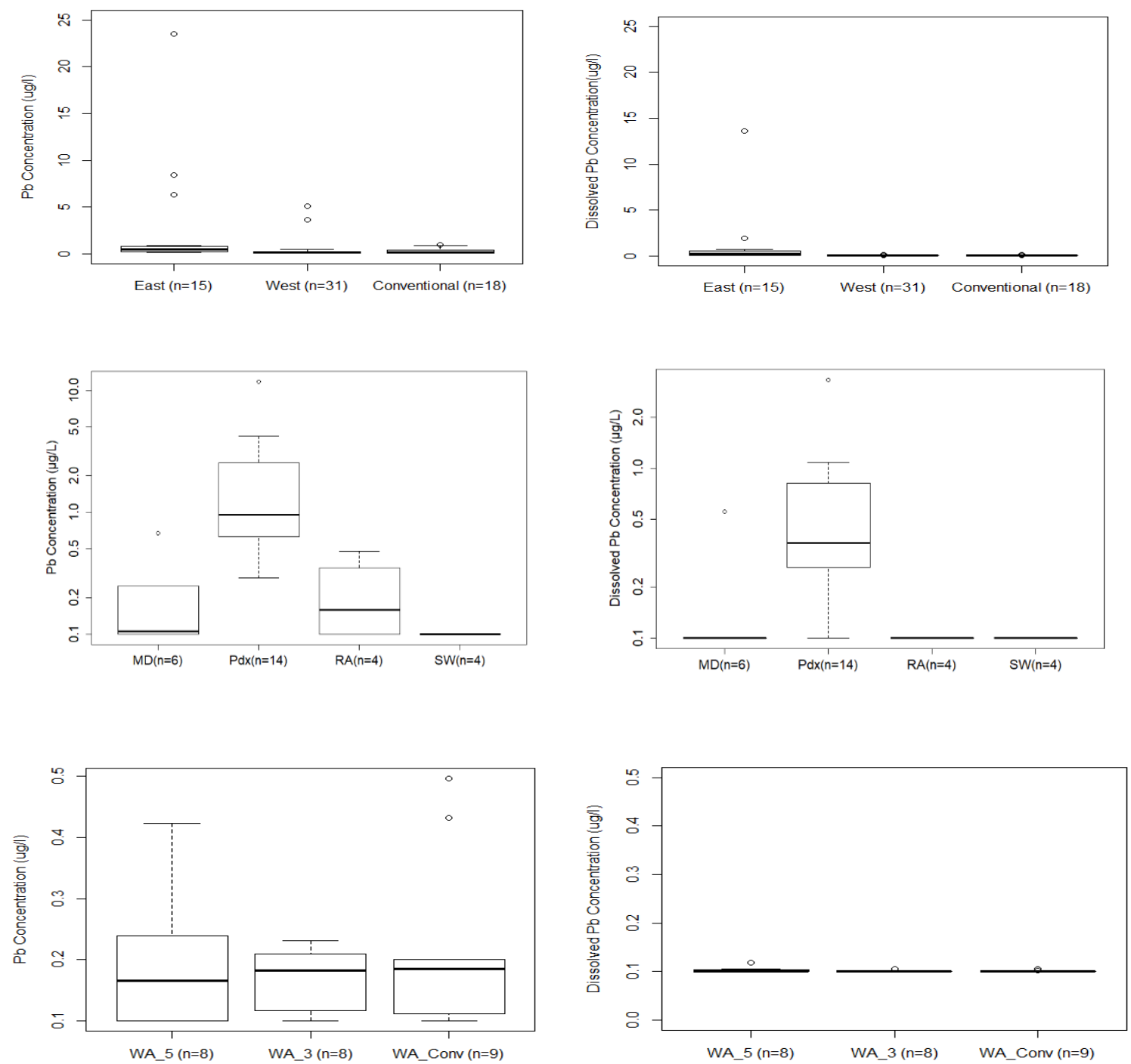

Figure 12: Boxplots showing total and dissolved Pb concentrations for all the sites

3.1.3 Zinc: The average concentration levels of $\mathrm{Zn}$ were much higher on HA east than on HA west $(55.85 \mu \mathrm{g} / \mathrm{L}$ total; $49.8 \mu \mathrm{g} / \mathrm{L}$ dissolved on east versus $20.7 \mu \mathrm{g} / \mathrm{L}$ total; $17.7 \mu \mathrm{g} / \mathrm{L}$ dissolved on west). The maximum concentration of total $\mathrm{Zn}$ on east side was $304 \mu \mathrm{g} / \mathrm{L}$ and that of dissolved $\mathrm{Zn}$ was $274 \mu \mathrm{g} / \mathrm{L}$. Galvanized metal railing on east side could be a source of higher concentration of $\mathrm{Zn}$ levels. The average concentration levels on HA conventional roof were much higher than 
Water Quality Analysis of Ecoroof Runoff in Portland

east and west ecoroof (335.2 $\mu \mathrm{g} / \mathrm{L}$ total; $305.9 \mu \mathrm{g} / \mathrm{L}$ dissolved). Similarly, WA conventional roof showed higher average $\mathrm{Zn}$ concentration than WA 5 and WA 3 ecoroofs $(40.96 \mu \mathrm{g} / \mathrm{L}$ total on conventional versus $19.5 \mu \mathrm{g} / \mathrm{L}$ on WA 5 and $19.01 \mu \mathrm{g} / \mathrm{L}$ on WA 3$)$. This would suggest the ecoroof can capture zinc from conventional roof sources like galvanized metals. The average concentration levels of Zn on MD $(62.6 \mu \mathrm{g} / \mathrm{L})$ and $\mathrm{SW}(54.3 \mu \mathrm{g} / \mathrm{L})$ were generally higher comparative to PDX $(17.9 \mu \mathrm{g} / \mathrm{L})$ and RA $(7.24 \mu \mathrm{g} / \mathrm{L})$ ecoroof. Boxplots for concentration of total and dissolved $\mathrm{Zn}$ are presented in figure 13.

MK test result showed decreasing concentrations on only the PDX site for total $\mathrm{Zn}$ and increasing concentration trend in dissolved $\mathrm{Zn}$ (Table 8). East HA also showed increasing concentration trend for total $\mathrm{Zn}$. Results from Mann Whitney U test showed significant difference in concentration of $\mathrm{Zn}$ for ecoroof and conventional roof (Table 9). 

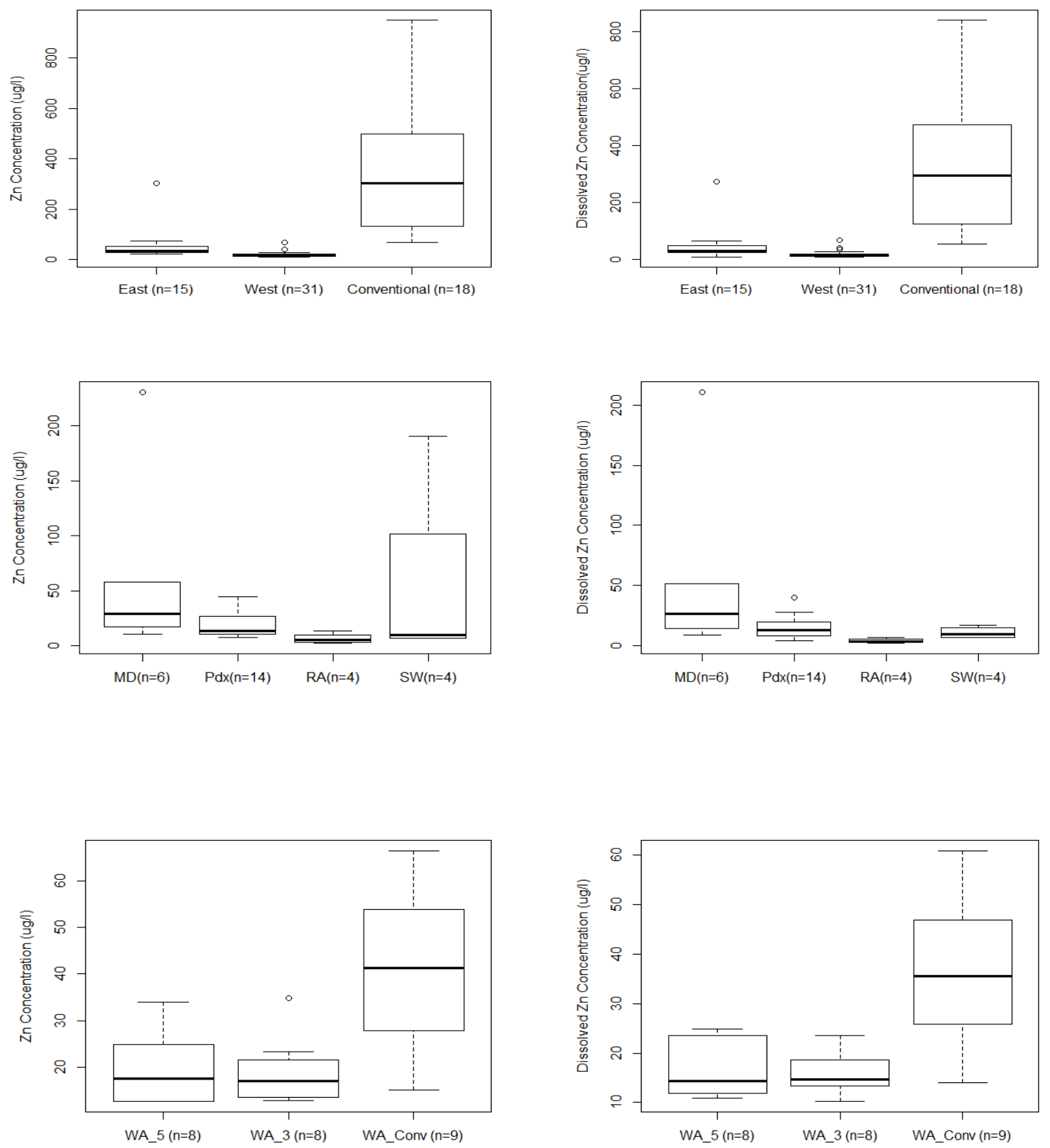

Figure 13: Boxplots showing total and dissolved Zn concentrations for all the sites

However, because of limited number of samples and scatter of data points, statistical trend tests did not provide satisfactory results, and graphical results showed downward trends in concentrations of metals over time (Appendix; Table 10). 


\subsection{Nutrients and Solids}

The concentrations of ammonia on all ecoroofs were relatively constant and much lower in concentration than water quality criteria levels. Boxplots for concentration of ammonia and nitrate are presented in Figure 14.

The average concentration of nitrate on HA west $(0.58 \mathrm{mg} / \mathrm{L})$ was higher than HA east $(0.34$ $\mathrm{mg} / \mathrm{L})$ and the conventional roof $(0.131 \mathrm{mg} / \mathrm{L})$. The maximum nitrate concentration on HA west was $10 \mathrm{mg} / \mathrm{L}$ and that of conventional roof was $0.57 \mathrm{mg} / \mathrm{L}$. All sites showed similar levels of nitrate concentration, ranging from $0.1 \mathrm{mg} / \mathrm{L}$ to $0.3 \mathrm{mg} / \mathrm{L}$, except PDX, where the maximum concentration was $3.2 \mathrm{mg} / \mathrm{L}$. However, average nitrate concentrations on all ecoroof as well as conventional roof sites were well below the water quality benchmark for streams.

Table 6: Oregon water quality criteria for nutrients

\begin{tabular}{lllll}
\hline Parameters (mg/L) & $\mathbf{N H}_{4}-\mathrm{N}$ & $\mathrm{NO}_{3}-\mathrm{N}$ & $\mathbf{P O}_{4}{ }^{-3}$ & $\mathbf{T P}$ \\
\hline Water Quality Criteria & 3.5 & $10^{*}$ & $\mathrm{~N} / \mathrm{A}$ & $0.13-0.16^{* *}$ \\
\hline
\end{tabular}

\footnotetext{
*Based on drinking water standards (Oregon Administrative Rule (OAR) 340-041 Table 33A), Criterion for $\mathrm{NH}_{4}-\mathrm{N}$ is a function of the $\mathrm{pH}$ and temperature.

**The Fanno Creek TMDL is $0.13 \mathrm{mg} / \mathrm{L}$ and the industrial NPDES permit benchmark is $0.16 \mathrm{mg} / \mathrm{L}$;
} 
Water Quality Analysis of Ecoroof Runoff in Portland

Table 7: Mean concentration of nutrients and TSS of ecoroof runoff for all sites

\begin{tabular}{|c|c|c|c|c|c|c|c|c|c|c|}
\hline \multicolumn{2}{|c|}{ Sites } \\
\hline Parameters & $\begin{array}{c}\text { HA } \\
\text { East }\end{array}$ & $\begin{array}{c}\text { HA } \\
\text { West }\end{array}$ & $\begin{array}{c}\text { HA } \\
\text { Conv }\end{array}$ & MD & PDX & RA & SW & WA 5 & WA 3 & WA \\
Conv
\end{tabular}

Results from MK test showed decreasing trend in nitrate on runoff from PDX site however, no trends were detected for ammonia on any site (Table 8). A significant difference was observed for nitrate concentrations and no difference for ammonia concentrations for ecoroof and conventional roof (Table 9). 

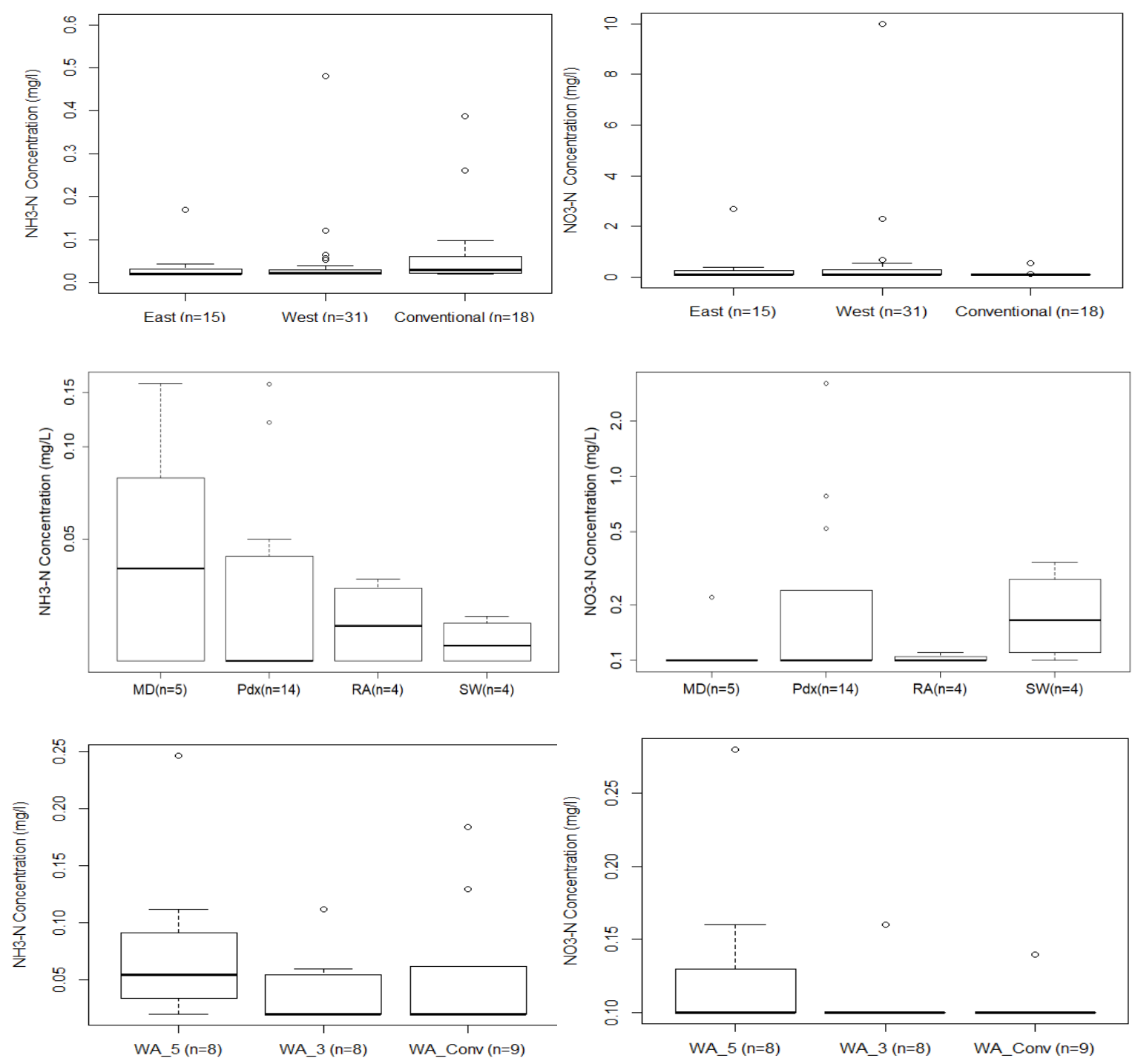

Figure 14: Boxplots showing ammonia and nitrate concentrations for all the sites

The average concentration of TP was higher in HA east $(0.28 \mathrm{mg} / \mathrm{L})$ and HA west $(0.33 \mathrm{mg} / \mathrm{L})$ than for the conventional roof $(0.038 \mathrm{mg} / \mathrm{L})$ and was higher than water quality criteria $(0.13-0.16$ $\mathrm{mg} / \mathrm{L}$ ) in streams. Similarly, all other ecoroof sites had TP concentrations higher than water quality benchmark in stream (ranging from $0.05 \mathrm{mg} / \mathrm{L}$ to $3.16 \mathrm{mg} / \mathrm{L}$ ) and $\mathrm{PO}_{4}{ }^{3}$ ranged from a minimum of 0.02 to a maximum $2.44 \mathrm{mg} / \mathrm{L}$. Conventional roof runoff from both HA and WA showed very little 
Water Quality Analysis of Ecoroof Runoff in Portland

or no presence of nutrients. This suggests that soil media and plant life cycles are important drivers of the nutrient runoff from ecoroofs. Boxplots for concentration of o-phosphate and TP are presented in Figure 15.

MK trend test result showed a decreasing trend in TP on HA east, HA west, PDX, WA5, WA3 and on both conventional roofs. Results for $\mathrm{PO}_{4}$ showed decreasing trends on PDX, HA east, and HA west. No trends were observed for other sites (Table 8).
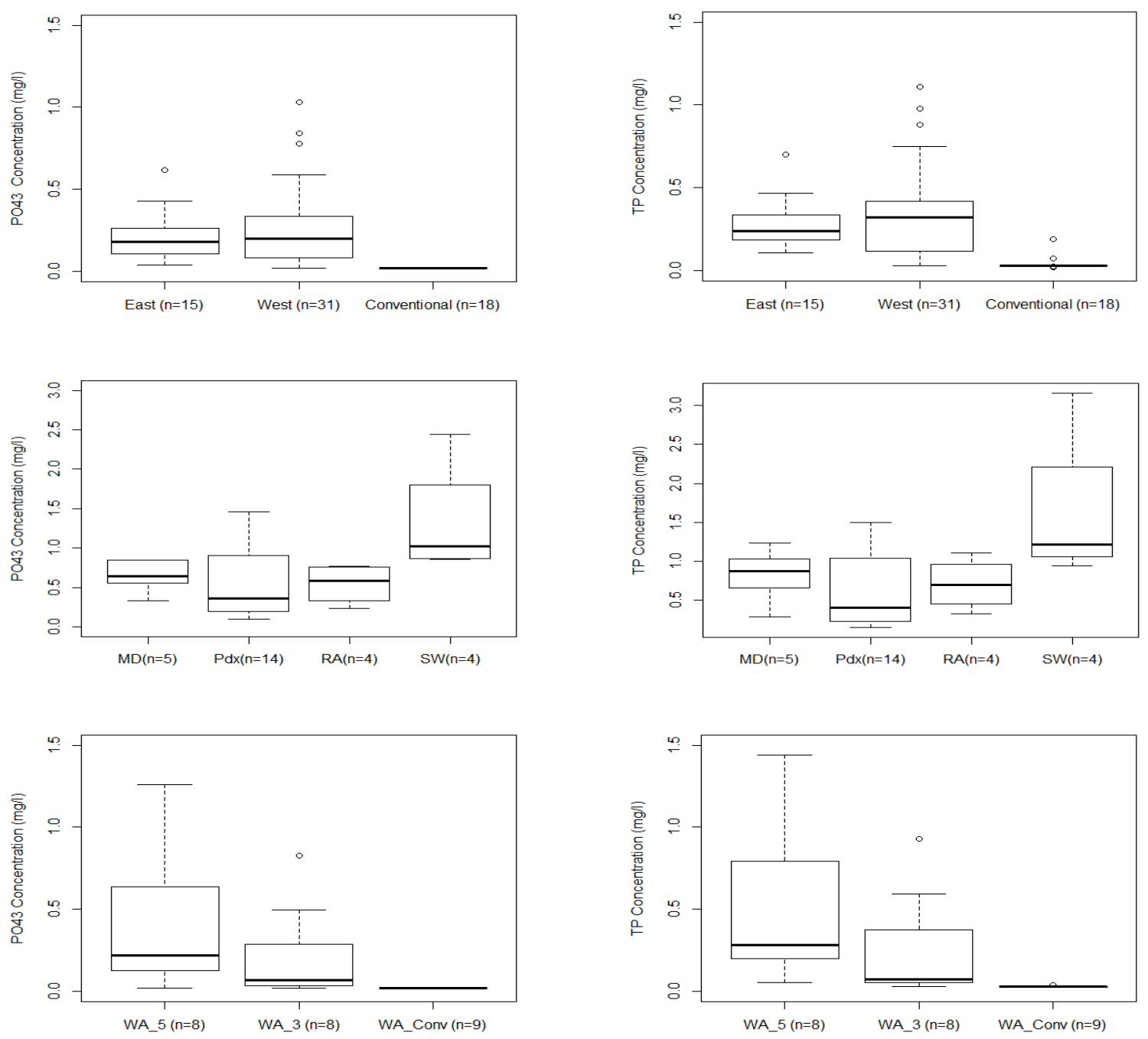

Figure 15: Boxplots showing o-phosphate and total phosphorous concentrations for all the sites 
Though descriptive statistical results showed elevated levels of phosphorus in ecoroof runoff, graphical results showed downward trends over time (Appendix; Figure 20).

TSS levels were higher for the HA west $(6.41 \mathrm{mg} / \mathrm{L})$ than HA east $(5.36 \mathrm{mg} / \mathrm{L})$ and conventional roof $(3.11 \mathrm{mg} / \mathrm{L})$. Runoff from all other ecoroof sites showed lower TSS level, averaging about $5 \mathrm{mg} / \mathrm{L}$. Boxplots for TSS concentration are presented in Figure 16.
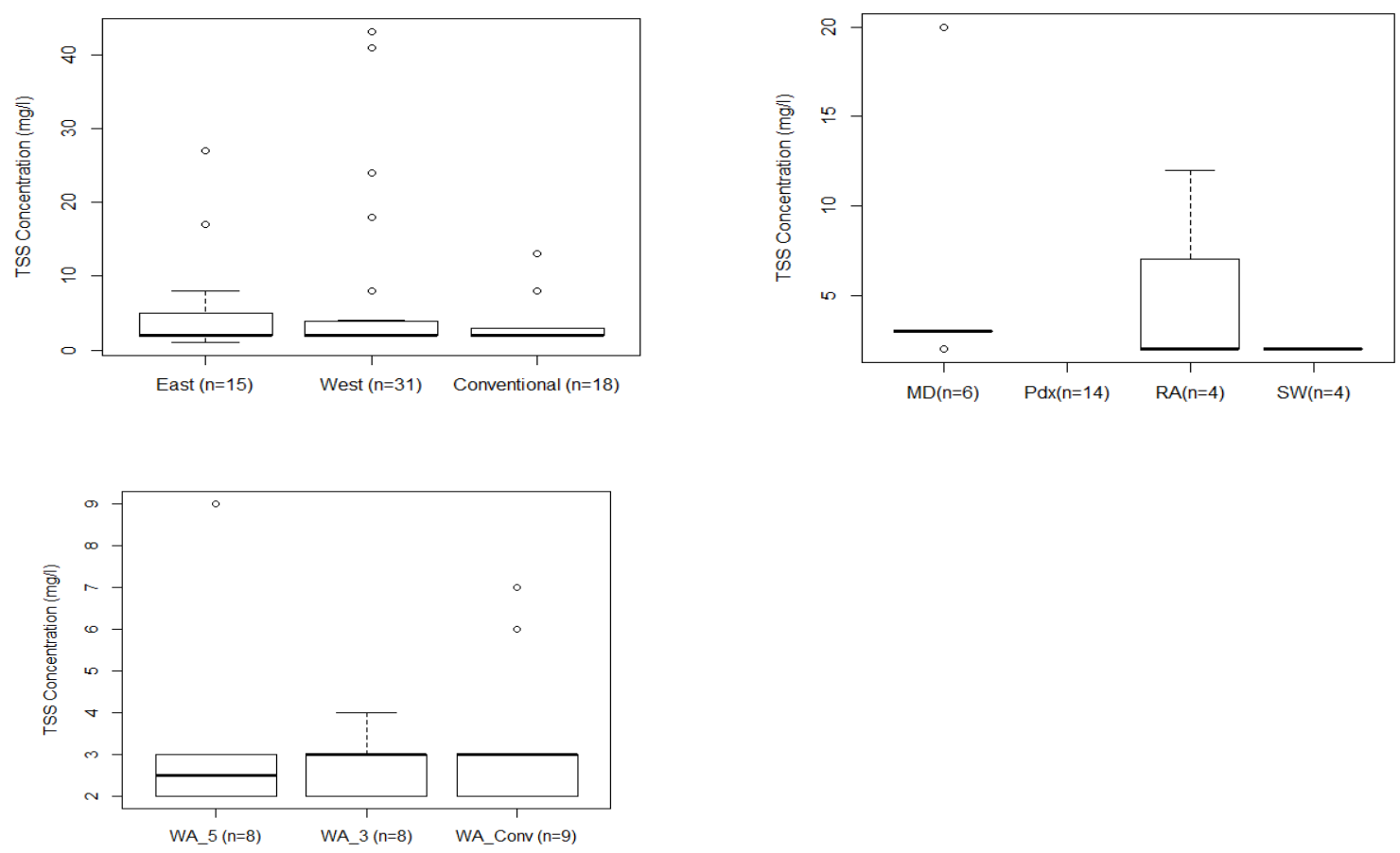

Figure 16: Boxplots showing total suspended solids concentrations for all the sites

Results from MK trend test showed increasing trend of TSS for HA east and conventional WA, however, no trend was detected on any other site. Mann Whitney U test showed no statistically significant difference in TSS concentration for ecoroof and conventional roof runoff.

Table 8 summarizes the results from MK trend tests for each site. Values in the ' $n$ ' row indicates number of samples used for the analysis. Colored boxes denote statistically significant result $(p$ value $<0.05)$ showing that there is a trend in the concentrations of the parameter. Red 
boxes with upward arrow indicate positive correlation (positive tau value) and shows increasing trend while blue boxes with downward arrows denote negative correlation indicating decreasing trend. All $p$ and tau values associated with each parameter for all sites are include in appendix (Table 11). Results indicated that, data from HA east runoff showed increasing trend in the concentration of total and dissolved $\mathrm{Pb}$, total $\mathrm{Zn}$, and TSS and decreasing trends of o-phosphate and TP. Concentration of $\mathrm{Pb}$, orthophosphate, and TP showed decreasing trend in $\mathrm{HA}$ west. Results from PDX site indicated decreasing trends in the concentration of total and dissolved $\mathrm{Cu}$, total $\mathrm{Zn}$, nitrate, and phosphorus and increasing trend in dissolved $\mathrm{Zn}$. A decreasing trend in TP concentration was also found in WA and HA sites. MK test failed to provide any results for MD, RA, and SW sites due to very limited number of samples.

Table 8: Results from MK trend test based on p and tau value

\begin{tabular}{|c|c|c|c|c|c|c|c|c|c|c|c|}
\hline \multirow[b]{2}{*}{ Parameter } & \multirow[b]{2}{*}{ Unit } & \multicolumn{3}{|c|}{ HA } & \multirow[b]{2}{*}{ MD } & \multirow[b]{2}{*}{ PDX } & \multirow[b]{2}{*}{ RA } & \multirow[b]{2}{*}{ SW } & \multirow[b]{2}{*}{$\begin{array}{c}\text { WA } \\
5\end{array}$} & \multirow[b]{2}{*}{$\begin{array}{c}\text { WA } \\
\mathbf{3}\end{array}$} & \multirow[b]{2}{*}{$\begin{array}{c}\text { WA } \\
\text { Conv }\end{array}$} \\
\hline & & East & West & Conv & & & & & & & \\
\hline $\mathbf{n}$ & & 13 & 31 & 18 & 5 & 12 & 4 & 4 & 8 & 8 & 8 \\
\hline $\mathrm{Cu}$ & (ug/l) & & & & & 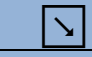 & & & & & \\
\hline $\mathrm{Cu}$ dissolved & $(\mathrm{ug} / \mathrm{l})$ & & & & & $\searrow$ & & & & & \\
\hline $\mathrm{Pb}$ & (ug/l) & 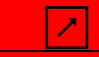 & 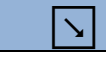 & & & & & & & & \\
\hline $\mathrm{Pb}$ dissolved & (ug/l) & $\lambda$ & & & & & & & & 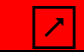 & \\
\hline $\mathrm{Zn}$ & (ug/l) & 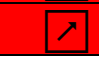 & & & & $\Delta$ & & & & & \\
\hline Zn dissolved & (ug/l) & & & & & 1 & & & & & \\
\hline $\mathrm{NH}_{4}-\mathrm{N}$ & $(\mathrm{mg} / \mathrm{L})$ & & & & & & & & & & \\
\hline $\mathrm{NO}_{3}-\mathrm{N}$ & $(\mathrm{mg} / \mathrm{L})$ & & & & & $\nabla$ & & & & & \\
\hline $\mathrm{PO}_{4}^{-3}$ & $(\mathrm{mg} / \mathrm{L})$ & 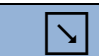 & $\nabla$ & & & 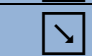 & & & & & \\
\hline $\mathrm{TP}$ & $(\mathrm{mg} / \mathrm{L})$ & 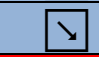 & $\searrow$ & 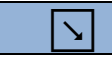 & & 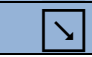 & & & 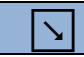 & 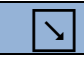 & $y$ \\
\hline TSS & $(\mathrm{mg} / \mathrm{L})$ & $r$ & & & & & & & & & 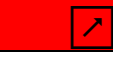 \\
\hline
\end{tabular}

Results from Mann-Whitney U test are included in Table 9. Colored boxes show the concentration distribution of conventional roof and ecoroof is significantly $(p<0.05)$ different. All $p$ values associated with each parameter for all sites are include in the Appendix (Table 12). Red boxes indicate higher concentrations of parameters in ecoroof runoff than conventional roof runoff. Blue 
boxes indicate lower concentrations of parameters in ecoroof runoff than conventional roof runoff.

Results indicated that almost all parameters showed significant difference in concentrations on HA East ecoroof and HA conventional roof except for dissolved $\mathrm{Pb}$ and TSS. Concentrations of total and dissolved $\mathrm{Pb}$, nitrate, and TSS did not show significant difference on HA west and HA conventional. Results for WA sites showed significance difference in concentrations of all parameters on ecoroof and conventional roof except for $\mathrm{Pb}$, nitrogen, and TSS.

Table 9: Results from Mann Whitney U Test

\begin{tabular}{|r|c|c|c|c|c|}
\hline Parameter & Unit & $\begin{array}{c}\text { Conventional } \\
\sim \text { HA East }\end{array}$ & $\begin{array}{c}\text { Conventional } \\
\sim \text { HA West }\end{array}$ & $\begin{array}{c}\text { Conventional } \\
\sim \text { WA 5 }\end{array}$ & $\begin{array}{c}\text { Conventional } \\
\sim \text { WA 3 }\end{array}$ \\
\hline $\mathbf{n}$ & & $\mathbf{1 3}$ & $\mathbf{1 8}$ & $\mathbf{8}$ & $\mathbf{8}$ \\
\hline $\mathrm{Cu}$ & $(\mathrm{ug} / \mathrm{l})$ & & & & \\
\hline $\mathrm{Cu}$ dissolved & $(\mathrm{ug} / \mathrm{l})$ & & & & \\
\hline $\mathrm{Pb}$ & $(\mathrm{ug} / \mathrm{l})$ & & & & \\
\hline $\mathrm{Pb}$ dissolved & $(\mathrm{ug} / \mathrm{l})$ & & & & \\
\hline $\mathrm{Zn}$ & $(\mathrm{ug} / \mathrm{l})$ & & & & \\
\hline $\mathrm{Zn}$ dissolved & $(\mathrm{ug} / \mathrm{l})$ & & & & \\
\hline $\mathrm{NH}_{4}-\mathrm{N}$ & $(\mathrm{mg} / \mathrm{L})$ & & & & \\
\hline $\mathrm{NO}_{3}-\mathrm{N}$ & $(\mathrm{mg} / \mathrm{L})$ & & & & \\
\hline $\mathrm{PO}_{4}{ }^{-3}$ & $(\mathrm{mg} / \mathrm{L})$ & & & & \\
\hline $\mathrm{TP}$ & $(\mathrm{mg} / \mathrm{L})$ & & & & \\
\hline $\mathrm{TSS}$ & $(\mathrm{mg} / \mathrm{L})$ & & & & \\
\hline
\end{tabular}




\section{Conclusions and Recommendations}

In this study, the trends in the long-term water quality data of runoff from six ecoroof sites were evaluated. Due to limited seasonal data, storm patterns, and lack of information about precipitation quality statistical trend tests did not provide conclusive results for some of the sites.

Copper: Results for $\mathrm{Cu}$ indicated higher levels of concentrations in runoff from ecoroof as compared to conventional roofs. Higher levels of $\mathrm{Cu}$ concentrations in the ecoroof runoff may be the result of $\mathrm{Cu}$ export from the soil media. Elevated $\mathrm{Cu}$ in runoff is a concern since slightest increase in levels of $\mathrm{Cu}$ can be harmful to aquatic life.

Lead: HA east and PDX showed higher level of $\mathrm{Pb}$ concentrations in ecoroof runoff than all other sites evaluated in this study. Higher $\mathrm{Pb}$ in the soil media on both sites might be the reason for elevated $\mathrm{Pb}$ in ecoroof runoff.

Zinc: This study found that $\mathrm{Zn}$ concentration in conventional roof runoff was higher than ecoroof runoff. Similar experimental studies conducted by Mendez et al. (2011) and Long et al. ( n.d.). also found higher concentrations of $\mathrm{Zn}$ in runoff from conventional metal roof. This contamination of runoff is likely due to roofing material in conventional roofs.

Nitrogen and Phosphorus: Ammonia and nitrate levels were significantly lower in ecoroof runoff for all sites. Phosphorus concentrations do appear to be significantly higher for ecoroofs. However, graphical results for sites (HA and WA) with long dataset exhibited downward trend over time. Decreasing trend in net export of phosphorus might be due to stabilization of soil media over time. A study by Long et. al (n.d.) at the Pennsylvania State University campus found similar results for the concentration of ammonia, nitrate, and TP. 


\section{Recommendations:}

- Higher P concentration in the runoff may be reduced by adding biochar amendment to the soil media. Study conducted by Gerould (2016) at Oregon State University also showed ability of different types of biochar to remove $\mathrm{Cu}$ in stormwater.

- To provide additional treatment, ecoroof runoff can be directed to other stormwater management facilities such as rain gardens (Barr, 2015). Runoff from ecoroof may also be reused for urban landscape irrigation or toilet flushing (Razzaghmanesh et al., 2016).

- To further evaluate concentrations of pollutants in ecoroof runoff and to study the effect of roof age on runoff, these roofs must be investigated for a longer period. For future water quality studies, it would be also beneficial to conduct more sampling in wet months.

- Also, it is recommended to evaluate first flush pollutant loading in ecoroof runoff as rainfall after dry period can produce greater pollutant loads than that of succeeding rainfall.

- It would be valuable to expand this water quality study to include precipitation quality. Having data for rainwater constituent levels would enable better understanding of the sources of pollutants in roof runoff. 
Water Quality Analysis of Ecoroof Runoff in Portland

\section{References}

Barr, C. M. (2015). WATER QUALITY IMPACTS OF A GREEN ROOF In Comparison to Other Land Uses, (December).

Berndtsson, J. C., Emilsson, T., \& Bengtsson, L. (2006). The influence of extensive vegetated roofs on runoff water quality. Science of the Total Environment, 355(1-3), 48-63. https://doi.org/10.1016/j.scitotenv.2005.02.035

BES, C. of P. (n.d.). No Title.

BES, C. of P. (2010a). Portland's Green Infrastructure : Quantifying the Health, Energy, and Community Livability Benefits.

BES, C. of P. (2010b). Stormwater Management Facility Monitoring Report SUMMARY Management Program.

Buffam, I., Mitchell, M. E., \& Durtsche, R. D. (2016). Environmental drivers of seasonal variation in green roof runoff water quality. Ecological Engineering, 91, 506-514. https://doi.org/10.1016/j.ecoleng.2016.02.044

Carpenter, C. M. G., Todorov, D., Driscoll, C. T., \& Montesdeoca, M. (2016). Water quantity and quality response of a green roof to storm events: Experimental and monitoring observations. Environmental Pollution, 218, 664-672. https://doi.org/10.1016/j.envpol.2016.07.056

Czemiel Berndtsson, J. (2010, April). Green roof performance towards management of runoff water quantity and quality: A review. Ecological Engineering.

https://doi.org/10.1016/j.ecoleng.2009.12.014

Ferrans, P., Rey, C. V., Pérez, G., Rodríguez, J. P., \& Díaz-Granados, M. (2018). Effect of green roof configuration and hydrological variables on runoffwater quantity and quality. Water (Switzerland), 10(7). https://doi.org/10.3390/w10070960

Gerould, J. M. D. (2016). Characterization of Biochar for Use in Treating Copper (II) Polluted Stormwater. Revista Brasileira de Ergonomia, 9(2), 10. https://doi.org/10.5151/cidi2017060

Gregoire, B. G., \& Clausen, J. C. (2011). Effect of a modular extensive green roof on stormwater runoff and water quality. Ecological Engineering, 37(6), 963-969. https://doi.org/10.1016/j.ecoleng.2011.02.004

Hutchinson, Doug. Abrams, peter. Retzalff, Ryan. Lipton, T. (2003). Stormwater monitoring two ecoroofs in Portland.pdf.

Jokimaa, C. S. (2016). Evaluation on the quality of green roof run off based on nutrients - Case study. 
Water Quality Analysis of Ecoroof Runoff in Portland

Li, Y., \& Babcock, R. W. (2014). Green roofs against pollution and climate change. A review. Agronomy for Sustainable Development, 34(4), 695-705. https://doi.org/10.1007/s13593014-0230-9

Long, B., Clark, S. E., Baker, K. H., \& Berghage, R. (n.d.). Green Roofs: Optimizing the Water Quality of Rooftop Runoff.

Mitchell, M. E., Matter, S. F., Durtsche, R. D., \& Buffam, I. (2017). Elevated phosphorus: dynamics during four years of green roof development. Urban Ecosystems, 20(5), 11211133. https://doi.org/10.1007/s11252-017-0664-3

Moran, A., Hunt, B., \& Jennings, G. (2004). A North Carolina Field Study to Evaluate Greenroof Runoff Quantity, Runoff Quality, and Plant Growth (pp. 1-10). American Society of Civil Engineers (ASCE). https://doi.org/10.1061/40685(2003)335

Portland, C. of. (2018). The cc2035 plan vision.

Razzaghmanesh, M., Beecham, S., \& Myers, B. (2016). Long-Term Effects of Green Roofs on Stormwater Quality from Two Sites in Australia. World Environmental And Water Resources Congress 2016: Water, Wastewater, and Stormwater and Urban Watershed Symposium - Papers from Sessions of the Proceedings of the 2016 World Environmental and Water Resources Congress, 371-379. https://doi.org/10.1061/9780784479889.039

Spolek, G. (2008). Performance monitoring of three ecoroofs in Portland, Oregon. Urban Ecosystems (Vol. 11). https://doi.org/10.1007/s11252-008-0061-z

Sullivan, L. (n.d.). Preliminary Study Comparing Precipitation Quality Between Nominal Land Uses in Portland, Oregon.

Susca, T., Gaffin, S. R., \& Dell'Osso, G. R. (2011). Positive effects of vegetation: Urban heat island and green roofs. Environmental Pollution, 159(8), 2119-2126. https://doi.org/https://doi.org/10.1016/j.envpol.2011.03.007

Teemusk, A. (2011). The Influence of Green Roofs on Runoff Water Quality : A Case Study from The Influence of Green Roofs on Runoff Water Quality : A Case Study from Estonia, (November). https://doi.org/10.1007/s11269-011-9877-z

Yang, J., Yu, Q., \& Gong, P. (2008). Quantifying air pollution removal by green roofs in Chicago. Atmospheric Environment, 42(31), 7266-7273.

https://doi.org/https://doi.org/10.1016/j.atmosenv.2008.07.003 
Water Quality Analysis of Ecoroof Runoff in Portland

\section{Appendix}

Table 10: Summary Statistics for all water quality parameters in runoff

\begin{tabular}{|c|c|c|c|c|c|c|c|c|c|c|c|}
\hline Parameters & $\begin{array}{r}\text { Summar } \\
\mathbf{y} \\
\text { Statistics }\end{array}$ & $\begin{array}{r}\text { HA } \\
\text { east }\end{array}$ & $\begin{array}{r}\text { HA } \\
\text { west }\end{array}$ & $\begin{array}{r}\text { HA } \\
\text { Conv }\end{array}$ & MD & PDX & $\mathbf{R A}$ & SW & WA 5 & WA 3 & $\begin{array}{r}\text { WA } \\
\text { Con } \\
\mathbf{v} \\
\end{array}$ \\
\hline \multirow[t]{4}{*}{ As $(\mu g / l)$} & Min & 0.44 & 0.1 & 0.1 & 1.42 & 0.10 & 0.20 & 2.31 & 0.46 & 0.25 & 0.10 \\
\hline & Median & 0.67 & 0.63 & 0.1 & 2.97 & 0.37 & 0.38 & 2.54 & 1.02 & 0.47 & 0.10 \\
\hline & Mean & 0.88 & 0.81 & 0.17 & 3.10 & 0.47 & 0.42 & 3.29 & 1.59 & 0.74 & 0.11 \\
\hline & Max & 1.5 & 2.29 & 0.82 & 5.54 & 1.36 & 0.75 & 5.48 & 3.53 & 1.86 & 0.20 \\
\hline \multirow[t]{4}{*}{$\begin{array}{c}\text { As dissolved } \\
(\mu \mathrm{g} / \mathrm{l})\end{array}$} & Min & 0.23 & 0.1 & 0.1 & 1.36 & 0.1 & 0.19 & 2.24 & 0.46 & 0.25 & 0.10 \\
\hline & Median & 0.65 & 0.57 & 0.10 & 2.68 & 0.37 & 0.29 & 2.43 & 0.97 & 0.45 & 0.10 \\
\hline & Mean & 0.79 & 0.67 & 0.17 & 2.90 & 0.49 & 0.34 & 3.32 & 1.54 & 0.72 & 0.10 \\
\hline & Max & 139 & 1.63 & 0.74 & 5.08 & 1.48 & 0.66 & 6.17 & 3.33 & 1.81 & 0.11 \\
\hline \multirow[t]{4}{*}{$\mathrm{Ca}(\mathrm{mg} / \mathrm{L})$} & Min & - & 0.22 & 0.27 & 27.20 & 13.80 & 20.50 & 17.90 & 26.10 & 16.50 & 0.20 \\
\hline & Median & - & 4.52 & 0.89 & 36.45 & 17.25 & 28.10 & 23.50 & 29.30 & 20.75 & 0.87 \\
\hline & Mean & - & 5.20 & 1.00 & 59.23 & 17.95 & 30.29 & 23.57 & 32.11 & 22.20 & 1.05 \\
\hline & Max & - & $\begin{array}{r}17.5 \\
0 \\
\end{array}$ & 2.41 & $\begin{array}{r}160.0 \\
0 \\
\end{array}$ & 23.50 & 40.00 & 29.40 & 45.20 & 34.30 & 2.25 \\
\hline \multirow[t]{4}{*}{$\operatorname{Mg}(\mathrm{mg} / \mathrm{L})$} & Min & - & 0.05 & 0.05 & 2.10 & 0.39 & 0.62 & 5.65 & 1.04 & 0.48 & 0.05 \\
\hline & Median & - & 1.77 & 0.10 & 4.10 & 0.50 & 1.38 & 8.02 & 3.17 & 1.40 & 0.05 \\
\hline & Mean & - & 2.06 & 0.11 & 7.59 & 0.52 & 1.73 & 8.52 & 3.74 & 2.00 & 0.06 \\
\hline & Max & - & 7.74 & 2.41 & 20.70 & 0.69 & 3.95 & 12.40 & 7.43 & 4.74 & 0.11 \\
\hline \multirow{4}{*}{$\begin{array}{c}\text { Conductivit } \\
y\end{array}$} & Min & 14 & 4 & 3 & 159 & 8 & 102 & 158 & 131 & 80 & 2 \\
\hline & Median & 59 & 61 & 10 & 206 & 170 & 150 & 177 & 198 & 140 & 9 \\
\hline & Mean & 65.5 & $\begin{array}{r}70.9 \\
5 \\
\end{array}$ & 11.17 & 237.6 & 152.7 & 154.8 & 212.2 & 206.1 & $\begin{array}{r}141.3 \\
8 \\
\end{array}$ & 12.11 \\
\hline & Max & $\begin{array}{r}122 \\
6 \\
\end{array}$ & 213 & 57 & 372 & 329 & 207 & 337 & 319 & 213 & 43 \\
\hline \multirow[t]{4}{*}{$\mathrm{Cr}$} & Min & 0.4 & $\begin{array}{r}0.27 \\
9 \\
\end{array}$ & 0.2 & 0.4 & 0.4 & 0.4 & 0.4 & 0.2 & 0.2 & 0.2 \\
\hline & Median & 0.90 & 0.82 & 0.40 & 0.58 & 0.40 & 0.40 & 0.54 & 0.30 & 0.30 & 0.29 \\
\hline & Mean & 0.90 & 1.00 & 0.4 & 0.95 & 0.47 & 0.41 & 0.56 & 0.32 & 0.30 & 0.32 \\
\hline & Max & 1.37 & 3.89 & 1.01 & 2.72 & 0.79 & 0.47 & 0.74 & 0.59 & 0.4 & 0.582 \\
\hline
\end{tabular}


Water Quality Analysis of Ecoroof Runoff in Portland

\begin{tabular}{|c|c|c|c|c|c|c|c|c|c|c|c|}
\hline Parameters & $\begin{array}{r}\text { Summar } \\
\mathbf{y} \\
\text { Statistics }\end{array}$ & $\begin{array}{l}\text { HA } \\
\text { east }\end{array}$ & $\begin{array}{r}\text { HA } \\
\text { west }\end{array}$ & $\begin{array}{r}\text { HA } \\
\text { Con } \\
\mathbf{v}\end{array}$ & MD & PDX & RA & SW & WA 5 & WA 3 & $\begin{array}{r}\text { WA } \\
\text { Con } \\
\text { v }\end{array}$ \\
\hline \multirow[t]{4}{*}{$\mathrm{Cu}(\mu \mathrm{g} / \mathrm{l})$} & Min & 4.85 & 0.78 & 0.54 & 4.08 & 2.95 & 3.55 & 4.02 & 2.13 & 2.41 & 0.28 \\
\hline & Median & 8.53 & $\begin{array}{r}10.1 \\
0\end{array}$ & 1.96 & 3.69 & 7.05 & 8.86 & 6.15 & 4.16 & 4.53 & 0.83 \\
\hline & Mean & 8.99 & $\begin{array}{r}11.8 \\
1\end{array}$ & 2.63 & 18.93 & 11.49 & 10.31 & 7.70 & 5.94 & 6.03 & 1.35 \\
\hline & Max & $\begin{array}{r}14.4 \\
0\end{array}$ & $\begin{array}{r}27.1 \\
0\end{array}$ & $\begin{array}{r}13.0 \\
0\end{array}$ & 72.80 & 38.60 & 18.80 & 14.50 & 18.30 & 19.50 & 3.17 \\
\hline \multirow{4}{*}{$\begin{array}{c}\mathrm{Cu} \\
\operatorname{Dissolved}(\mu \mathrm{g} / \mathrm{l})\end{array}$} & Min & 3.39 & 0.50 & 0.27 & 3.64 & 1.70 & 3.01 & 3.65 & 2.04 & 2.36 & 0.20 \\
\hline & Median & 5.34 & 8.90 & 1.09 & 7.87 & 6.87 & 8.16 & 5.89 & 3.74 & 4.15 & 0.39 \\
\hline & Mean & 7.28 & $\begin{array}{r}10.3 \\
6\end{array}$ & 1.90 & 16.16 & 10.07 & 9.38 & 7.61 & 5.55 & 5.59 & 0.46 \\
\hline & Max & 7.83 & $\begin{array}{r}26.3 \\
0\end{array}$ & $\begin{array}{r}10.2 \\
0\end{array}$ & 59.40 & 34.70 & 18.10 & 15.00 & 18.30 & 19.10 & 0.83 \\
\hline \multirow{4}{*}{$\begin{array}{c}\text { Ecoli(MPN/10 } \\
\text { 0) }\end{array}$} & Min & 1 & 1 & 1 & 1 & 1 & 10 & 1 & 10 & 10 & 10 \\
\hline & Median & 10 & 10 & 10 & 10 & 10 & 10 & 10.5 & 10 & 10 & 10 \\
\hline & Mean & $\begin{array}{r}435 . \\
3 \\
\end{array}$ & $\begin{array}{r}151 . \\
5\end{array}$ & $\begin{array}{r}229 . \\
7\end{array}$ & 7.4 & 249.5 & 97.5 & 33 & 15.25 & $\begin{array}{r}217.6 \\
2 \\
\end{array}$ & $\begin{array}{r}47.5 \\
6 \\
\end{array}$ \\
\hline & Max & 2400 & 2200 & 3400 & 10 & 3300 & 560 & 110 & 52 & 1400 & 230 \\
\hline \multirow[t]{4}{*}{$\begin{array}{l}\text { Hardness (mg } \\
\text { CaCo3) }\end{array}$} & Min & 25.2 & $\begin{array}{r}0.55 \\
2\end{array}$ & $\begin{array}{r}0.68 \\
3\end{array}$ & 82.7 & 34 & 54.1 & 68 & 69.5 & 43.3 & 0.71 \\
\hline & Median & 37.8 & 20.8 & 2.38 & 107.5 & 81.3 & 75.85 & 91.7 & 69.75 & 62.5 & 2.27 \\
\hline & Mean & $\begin{array}{r}36.7 \\
2\end{array}$ & $\begin{array}{r}28.7 \\
4\end{array}$ & 2.42 & $\begin{array}{r}179.0 \\
7\end{array}$ & 82.26 & 82.76 & 94.1 & 95.56 & 63.69 & 2.76 \\
\hline & Max & 49.6 & 75.6 & 7.1 & 485 & 206 & 110 & 125 & 126 & 91.6 & 5.86 \\
\hline \multirow{4}{*}{$\begin{array}{c}\text { Ammonia } \\
(\mathrm{mg} / \mathrm{L})\end{array}$} & Min & 0.02 & 0.02 & 0.02 & 0.02 & 0.02 & 0.02 & 0.02 & 0.02 & 0.02 & 0.02 \\
\hline & Median & 0.02 & 0.02 & 0.03 & 0.04 & 0.02 & 0.03 & 0.02 & 0.05 & 0.02 & 0.02 \\
\hline & Mean & 0.04 & 0.05 & 0.07 & 0.06 & 0.04 & 0.03 & 0.02 & 0.08 & 0.04 & 0.06 \\
\hline & Max & 0.17 & 0.48 & 0.39 & 0.16 & 0.16 & 0.07 & 0.03 & 0.25 & 0.11 & 0.18 \\
\hline \multirow[t]{4}{*}{ Nitrate(mg/L) } & Min & 0.10 & 0.10 & 0.10 & 0.10 & 0.10 & 0.10 & 0.10 & 0.10 & 0.10 & 0.10 \\
\hline & Median & 0.12 & 0.10 & 0.10 & 0.10 & 0.10 & 0.10 & 0.17 & 0.10 & 0.10 & 0.10 \\
\hline & Mean & 0.34 & 0.58 & 0.13 & 0.12 & 0.41 & 0.12 & 0.19 & 0.13 & 0.11 & 0.10 \\
\hline & Max & 2.7 & 10 & 0.57 & 0.22 & 3.2 & 0.24 & 0.34 & 0.28 & 0.16 & 0.14 \\
\hline \multirow{4}{*}{$\begin{array}{c}\text { o-Phosphate } \\
\text { (mg/L) }\end{array}$} & Min & 0.04 & 0.02 & 0.02 & 0.33 & 0.10 & 0.08 & 0.86 & 0.02 & 0.02 & 0.02 \\
\hline & Median & 0.18 & 0.20 & 0.02 & 0.64 & 0.36 & 0.37 & 1.02 & 0.22 & 0.07 & 0.02 \\
\hline & Mean & 0.22 & 0.26 & 0.02 & 0.64 & 0.56 & 0.40 & 1.34 & 0.41 & 0.20 & 0.02 \\
\hline & Max & 0.62 & 0.34 & 0.02 & 0.85 & 1.46 & 0.77 & 2.44 & 1.26 & 0.83 & 0.02 \\
\hline \multirow[t]{4}{*}{$\mathrm{TP}(\mathrm{mg} / \mathrm{L})$} & Min & 0.11 & 0.03 & 0.02 & 0.28 & 0.15 & 0.15 & 0.94 & 0.05 & 0.03 & 0.03 \\
\hline & Median & 0.24 & 0.32 & 0.03 & 0.87 & 0.41 & 0.47 & 1.22 & 0.28 & 0.07 & 0.03 \\
\hline & Mean & 0.29 & 0.34 & 0.04 & 0.82 & 0.64 & 0.54 & 1.64 & 0.51 & 0.25 & 0.03 \\
\hline & Max & 0.70 & 1.11 & 0.19 & 1.23 & 1.50 & 1.11 & 3.16 & 1.44 & 0.93 & 0.04 \\
\hline
\end{tabular}


Water Quality Analysis of Ecoroof Runoff in Portland

\begin{tabular}{|c|c|c|c|c|c|c|c|c|c|c|c|}
\hline Parameters & $\begin{array}{r}\text { Summar } \\
y \\
\text { Statistics }\end{array}$ & $\begin{array}{r}\text { HA } \\
\text { east }\end{array}$ & $\begin{array}{r}\text { HA } \\
\text { west }\end{array}$ & $\begin{array}{r}\text { HA } \\
\text { Conv }\end{array}$ & MD & PDX & RA & SW & $\begin{array}{r}\text { WA } \\
5\end{array}$ & $\begin{array}{r}\text { WA } \\
\mathbf{3}\end{array}$ & $\begin{array}{r}\text { WA } \\
\text { Con } \\
\text { v }\end{array}$ \\
\hline \multirow[t]{4}{*}{$\mathrm{Pb}(\mu \mathrm{g} / \mathrm{L})$} & Min & 0.16 & 0.10 & 0.10 & 0.10 & 0.29 & 0.10 & 0.10 & 0.10 & 0.10 & 0.10 \\
\hline & Median & 0.47 & 0.16 & 0.20 & 0.11 & 0.96 & 0.10 & 0.10 & 0.17 & 0.18 & 0.19 \\
\hline & Mean & 2.86 & 0.46 & 0.35 & 0.22 & 2.10 & 0.17 & 0.10 & 0.19 & 0.17 & 0.22 \\
\hline & Max & $\begin{array}{r}23.5 \\
0\end{array}$ & 5.12 & 1.02 & 0.67 & 11.80 & 0.48 & 0.10 & 0.42 & 0.23 & 0.50 \\
\hline \multirow{4}{*}{$\begin{array}{c}\text { Pb dissolved } \\
(\mu \mathrm{g} / \mathrm{L})\end{array}$} & Min & 0.10 & 0.13 & 0.10 & 0.10 & 0.10 & 0.10 & 0.10 & 0.10 & 0.10 & 0.10 \\
\hline & Median & 0.27 & 0.21 & 0.10 & 0.10 & 0.36 & 0.10 & 0.10 & 0.10 & 0.10 & 0.10 \\
\hline & Mean & 1.29 & 0.45 & 0.10 & 0.18 & 0.66 & 0.10 & 0.10 & 0.10 & 0.10 & 0.10 \\
\hline & Max & $\begin{array}{r}13.6 \\
0\end{array}$ & 1.02 & 0.14 & 0.55 & 3.32 & 0.10 & 0.10 & 0.12 & 0.11 & 0.11 \\
\hline \multirow[t]{4}{*}{ pH } & Min & 4.8 & 5.1 & 5.1 & 7.5 & 6.3 & 7.3 & 7.9 & - & - & - \\
\hline & Median & 6 & 6.3 & 6.8 & 7.9 & 7 & 7.75 & 8.1 & - & - & - \\
\hline & Mean & 6.05 & 6.27 & 6.81 & 7.88 & 7.09 & 7.91 & 8.45 & - & - & - \\
\hline & Max & 6.8 & 7.3 & 9.8 & 8.2 & 7.9 & 9.3 & 9.7 & - & - & - \\
\hline \multirow[t]{4}{*}{ TS (mg/L) } & Min & 49 & 2 & 2 & 116 & 53 & 68 & 114 & 104 & 71 & 2 \\
\hline & Median & 91 & 106 & 6.5 & 289 & 145.5 & 134 & 143 & 143 & 100 & 8 \\
\hline & Mean & $\begin{array}{r}92.4 \\
7\end{array}$ & $\begin{array}{r}111 . \\
4\end{array}$ & 9 & 398.5 & 151.3 & 138.1 & 187 & 164.2 & 100.6 & $\begin{array}{r}7.55 \\
6\end{array}$ \\
\hline & Max & 160 & 274 & 35 & 985 & 425 & 222 & 348 & 301 & 166 & 19 \\
\hline \multirow[t]{4}{*}{ TDS (mg/L) } & Min & 17 & 5 & 5 & 113 & 49 & 74 & 118 & 94 & 45 & 5 \\
\hline & Median & 91 & 82 & 5 & 256.5 & 132 & 123 & 132 & 146.5 & 96.5 & 6 \\
\hline & Mean & 85.9 & $\begin{array}{r}100 . \\
6 \\
\end{array}$ & 6.611 & 352.8 & 139.3 & 126 & 161.5 & 161.1 & 100.1 & 8.44 \\
\hline & $\operatorname{Max}$ & 141 & 266 & 11 & 883 & 372 & 196 & 264 & 280 & 157 & 20 \\
\hline \multirow[t]{4}{*}{ TSS (mg/L) } & Min & 1 & 2 & 2 & 2 & 2 & 2 & 2 & 2 & 2 & 2 \\
\hline & Median & 2 & 2 & 2 & 3 & 3.5 & 2 & 2 & 2.5 & 3 & 3 \\
\hline & Mean & $\begin{array}{r}5.36 \\
7\end{array}$ & 6.41 & 3.11 & 6.2 & 4.429 & 3.25 & 2 & 3.25 & 2.75 & 3.33 \\
\hline & Max & 27 & 43.2 & 13 & 20 & 16 & 12 & 2 & 9 & 4 & 7 \\
\hline \multirow[t]{4}{*}{$\operatorname{Zn}(\mu \mathrm{g} / \mathrm{L})$} & Min & 20.3 & 8.87 & 67.8 & 10 & 7.52 & 2.25 & 6.98 & 12.6 & 12.8 & 15.1 \\
\hline & Median & 33.3 & 16.7 & 302 & 29.45 & 13.35 & 6.35 & 9.615 & 17.6 & 17 & 41.2 \\
\hline & Mean & $\begin{array}{r}55.8 \\
5\end{array}$ & 20.7 & 335.2 & 62.6 & 17.99 & 7.24 & 54.30 & 19.57 & 19.01 & $\begin{array}{r}40.9 \\
6\end{array}$ \\
\hline & $\operatorname{Max}$ & 304 & 69.1 & 952 & 231 & 44.3 & 13.7 & 191 & 33.9 & 34.9 & 66.5 \\
\hline \multirow{4}{*}{$\begin{array}{c}\mathrm{Zn} \\
\operatorname{dissolved}(\mu \mathrm{g} / \mathrm{L} \\
)\end{array}$} & Min & 9.08 & 7.56 & 55.2 & 8.73 & 4.23 & 1.7 & 6.65 & 10.9 & 10.2 & 14 \\
\hline & Median & 29.1 & 13.6 & 295 & 26.5 & 12.75 & 4 & 9.435 & 14.3 & 14.6 & 35.6 \\
\hline & Mean & 49.8 & 17.7 & 305.9 & 56.32 & $\begin{array}{r}15.57 \\
6 \\
\end{array}$ & 5.216 & $\begin{array}{r}10.65 \\
5 \\
\end{array}$ & 16.91 & 15.84 & $\begin{array}{r}35.1 \\
4 \\
\end{array}$ \\
\hline & Max & 274 & 68 & 841 & 211 & 39.7 & 10.7 & 17.1 & 24.8 & 23.6 & 60.9 \\
\hline
\end{tabular}


Water Quality Analysis of Ecoroof Runoff in Portland
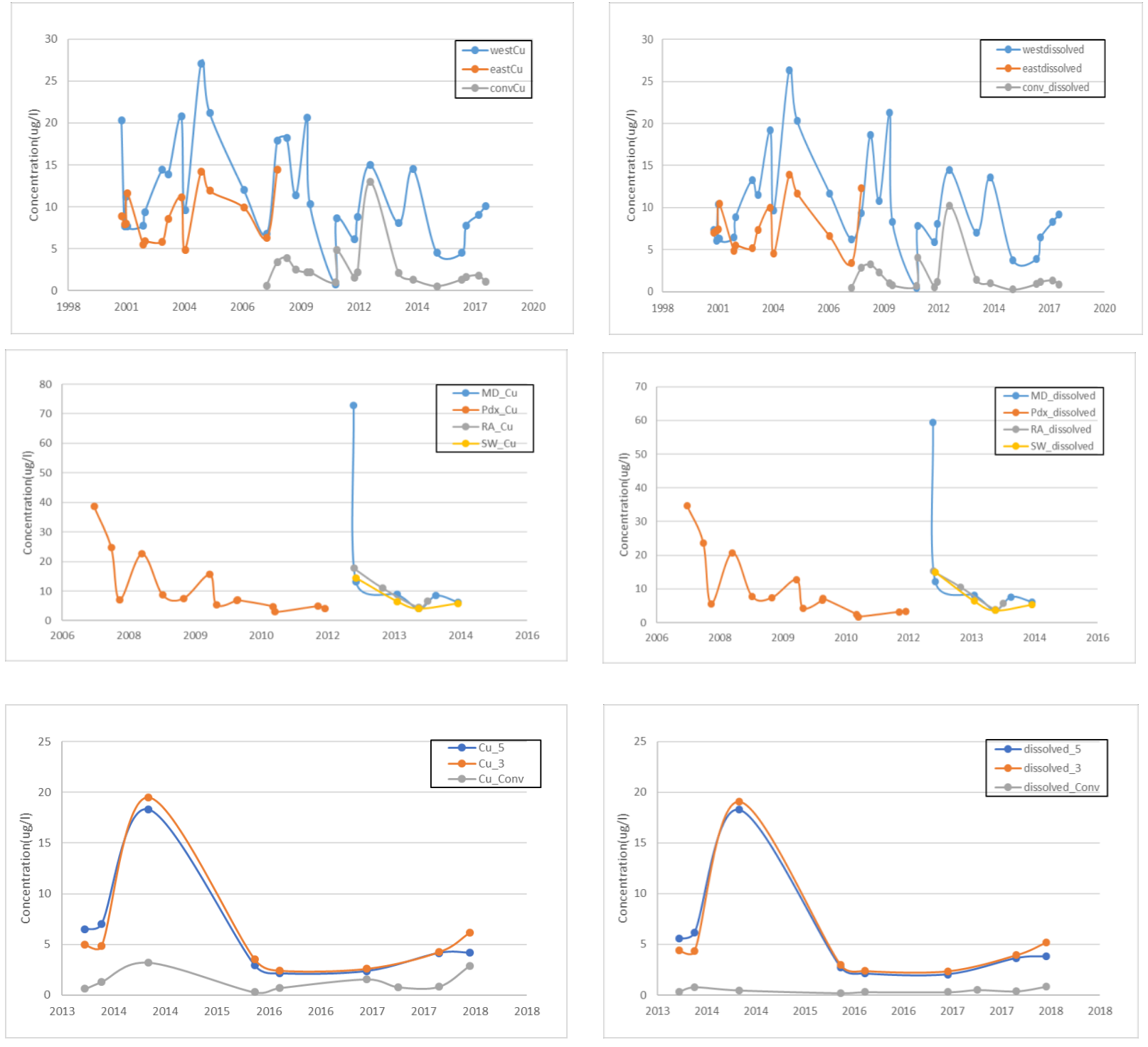

Figure 17: Graphical representation of concentrations of $\mathrm{Cu}$ and $\mathrm{Cu}$ dissolved in ecoroof runoff 
Water Quality Analysis of Ecoroof Runoff in Portland
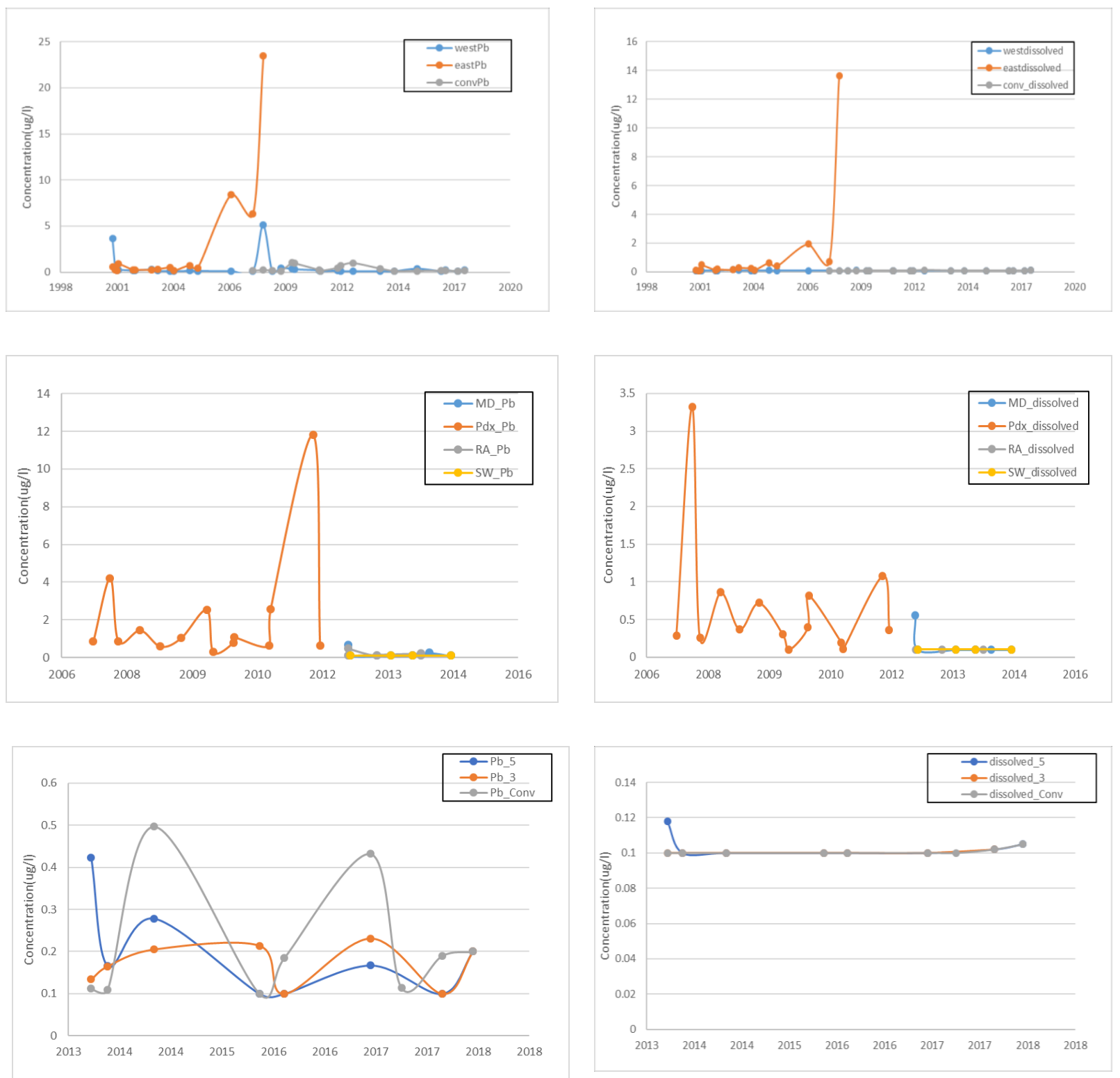

Figure 18: Graphical representation of Concentration of $\mathrm{Pb}$ and $\mathrm{Pb}$ dissolved in ecoroof runoff 
Water Quality Analysis of Ecoroof Runoff in Portland
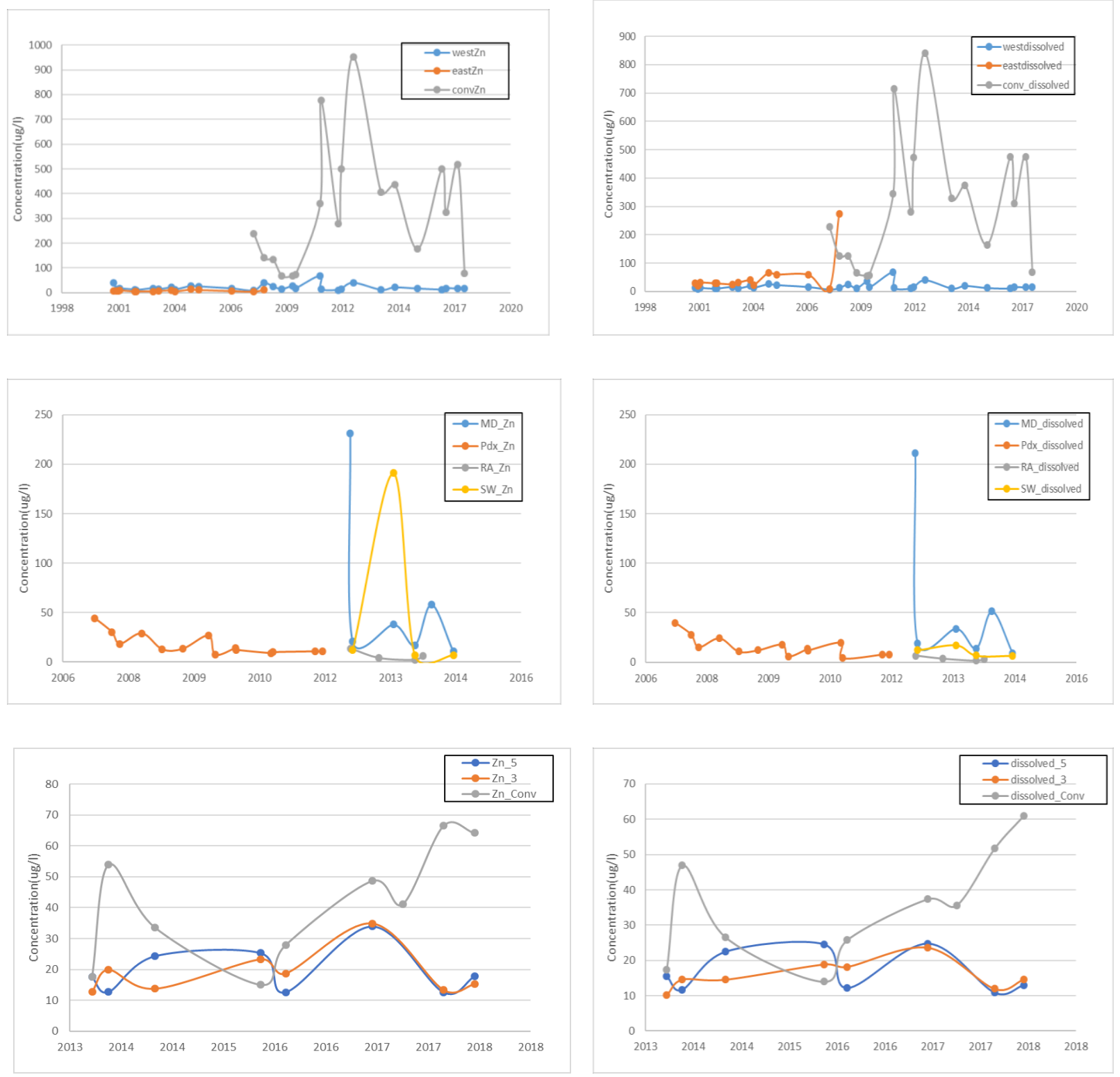

Figure 19: Graphical representation of Concentration of $Z n$ and $Z n$ dissolved in ecoroof runoff 
Water Quality Analysis of Ecoroof Runoff in Portland
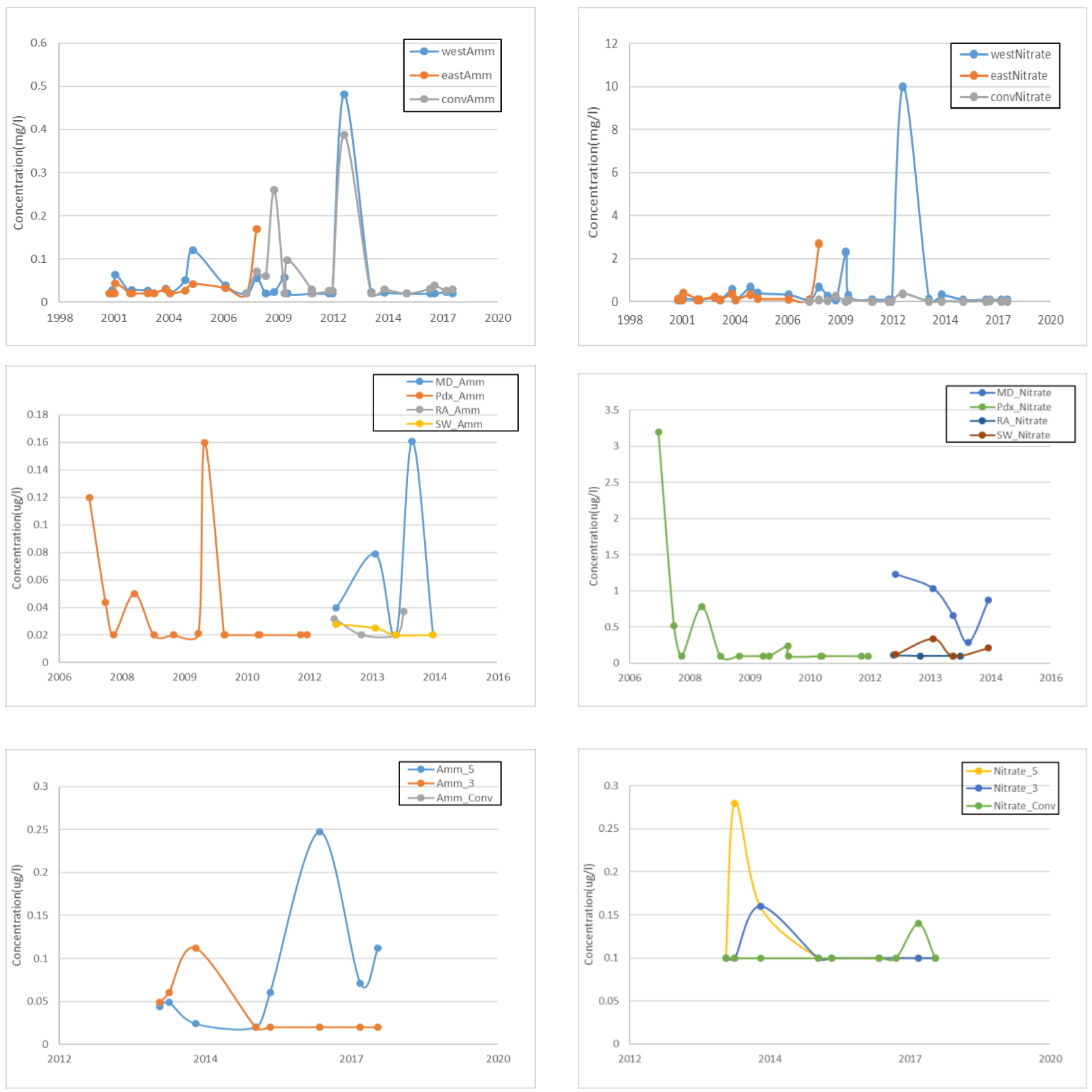

Figure 20:Graphical representation of Concentration of Ammonia and Nitrate in ecoroof runoff 
Water Quality Analysis of Ecoroof Runoff in Portland
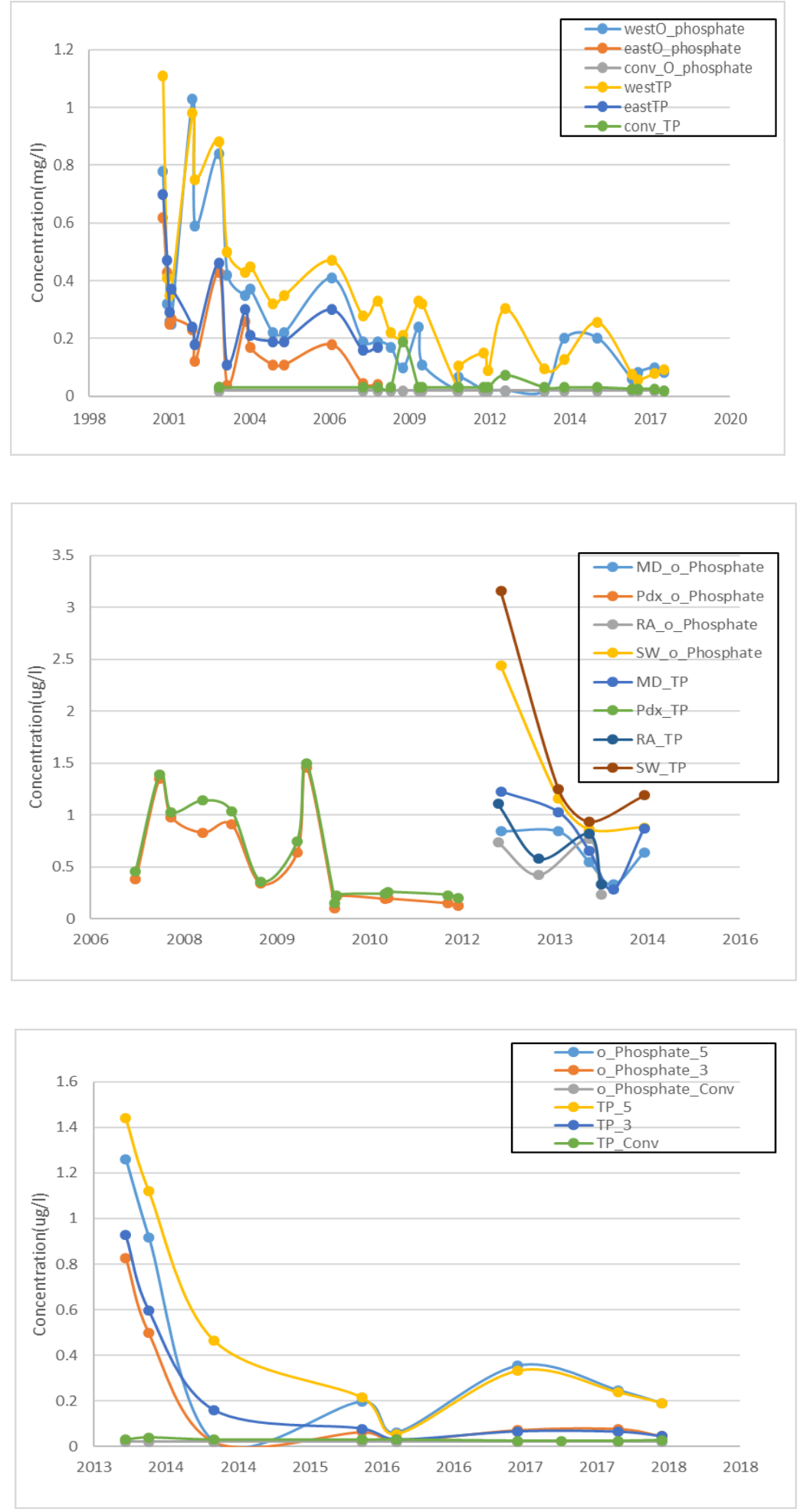

Figure 21: Graphical representation of Concentration of o-Phosphate and TP in ecoroof runoff 
Water Quality Analysis of Ecoroof Runoff in Portland

Table 11: Results from Mann Kendall Trend Test

\begin{tabular}{|c|c|c|c|c|c|c|c|c|c|c|c|}
\hline Parameters & $\begin{array}{l}\text { MK } \\
\text { Trend }\end{array}$ & HA east & HA west & HA Conv & MD & Pdx & RA & SW & WA 5 & WA 3 & $\begin{array}{l}\text { WA } \\
\text { Conv }\end{array}$ \\
\hline \multirow[t]{2}{*}{$\mathrm{Cu}(\mu \mathrm{g} / \mathrm{I})$} & tau value & 0.219 & -0.178 & -0.262 & -0.733 & -0.736 & -0.286 & -0.667 & -0.214 & -0.143 & 0.278 \\
\hline & $p$-value & 0.0857 & -0.099 & -0.105 & 0.0603 & 0.0003 & 0.3865 & 0.3082 & 0.53619 & 0.7105 & .348 \\
\hline \multirow{2}{*}{$\begin{array}{c}\mathrm{Cu} \\
\operatorname{dissolved}(\mu \mathrm{g} / \mathrm{l})\end{array}$} & tau value & 0.0857 & -0.099 & -0.105 & -0.733 & -0.648 & -0.286 & -0.667 & -0.286 & -0.214 & 0.222 \\
\hline & $p$-value & 0.69218 & 0.4443 & 0.5697 & 0.0603 & 0.0015 & 0.3865 & 0.3082 & 0.348 & 0.5362 & .466 \\
\hline \multirow[t]{2}{*}{$\mathrm{Pb}(\mu \mathrm{g} / \mathrm{I})$} & tau value & 0.448 & -0.232 & -0.124 & -0.276 & 0.033 & -0.178 & Error & -0.265 & 0.109 & 0.278 \\
\hline & $p$-value & 0.0228 & 0.0749 & 0.4954 & 0.5661 & 0.9128 & 0.6672 & Error & 0.4448 & 0.8031 & 0.348 \\
\hline \multirow{2}{*}{$\begin{array}{l}\text { Pb dissolved } \\
(\mu \mathrm{g} / \mathrm{l})\end{array}$} & tau value & 0.644 & 0.029 & 0.397 & -0.577 & -0.099 & Error & Error & 0.178 & 0.681 & 0.645 \\
\hline & $p$-value & 0.00106 & 0.86224 & & 0.2416 & 0.6614 & Error & Error & 0.66717 & 0.0485 & 0.043 \\
\hline \multirow[t]{2}{*}{$\mathrm{Zn}(\mu \mathrm{g} / \mathrm{I})$} & tau value & 0.352 & 0.0539 & 0.281 & -0.467 & -0.604 & -0.109 & -0.333 & 0.0364 & 0.143 & 0.44 \\
\hline & $p$-value & 0.0748 & 0.6832 & 0.1116 & 0.2597 & 0.0031 & 0.8031 & 0.7341 & 1 & 0.7105 & 0.118 \\
\hline \multirow{2}{*}{$\begin{array}{c}\text { Zn dissolved } \\
(\mu \mathrm{g} / \mathrm{I})\end{array}$} & tau value & 0.314 & 0.162 & 0.262 & -0.467 & -0.538 & 0.0714 & -0.667 & 0 & 0.265 & 0.5 \\
\hline & $p$-value & 0.113 & 0.208 & 0.1393 & 0.2597 & 0.0086 & 0.9015 & 0.3082 & 1 & 0.4448 & 0.076 \\
\hline \multirow[t]{2}{*}{ Ammonia (mg/l) } & tau value & 0.411 & -0.223 & -0.047 & -0.105 & -0.438 & 0.189 & -0.913 & 0.5 & -0.535 & -0.182 \\
\hline & $p$-value & 0.05592 & 0.0994 & 0.8189 & 1 & 0.0536 & 0.6105 & 0.148 & 0.10776 & 0.114 & 0.616 \\
\hline \multirow[t]{2}{*}{ Nitrate $(\mathrm{mg} / \mathrm{l})$} & tau value & 0.103 & -0.0237 & 0.32 & 0.316 & -0.495 & -0.262 & 0 & -0.475 & -0.214 & 0.354 \\
\hline & $p$-value & 0.6443 & 0.879 & 0.1104 & 0.7237 & 0.0318 & 0.5108 & 1 & 0.18845 & 0.6625 & 0.333 \\
\hline \multirow{2}{*}{$\begin{array}{c}\text { o- } \\
\text { Phosphate }(\mathrm{mg} / \mathrm{I})\end{array}$} & tau value & -0.606 & -0.599 & Error & -0.6 & -0.56 & -0.571 & -0.667 & -0.286 & -0.214 & Error \\
\hline & $p$-value & 0.0021 & $3.02 \mathrm{E}-06$ & Error & 0.2207 & 0.0062 & 0.0635 & 0.3081 & 0.38648 & 0.5362 & Error \\
\hline \multirow[t]{2}{*}{$\mathrm{TP}(\mathrm{mg} / \mathrm{l})$} & tau value & -0.51 & -0.682 & -0.474 & -0.6 & -0.486 & -0.571 & -0.667 & -0.643 & -0.786 & -0.609 \\
\hline & $p$-value & 0.00989 & 8.50E-08 & 0.0109 & 0.2207 & 0.0184 & 0.0635 & 0.3082 & 0.03545 & 0.0094 & 0.044 \\
\hline \multirow[t]{2}{*}{ TSS (mg/l) } & tau value & 0.358 & -0.14 & 0.305 & -0.12 & -0.061 & -0.5 & Error & 0.217 & -0.13 & 0.738 \\
\hline & $p$-value & 0.08393 & 0.3216 & 0.1325 & 1 & 0.8179 & 0.1904 & Error & 0.5827 & 0.7835 & 0.014 \\
\hline
\end{tabular}


Water Quality Analysis of Ecoroof Runoff in Portland

Table 12: Results from Mann Whitney U test

\begin{tabular}{|c|c|c|c|c|c|}
\hline Parameters & $\begin{array}{c}\text { Mann } \\
\text { Whitney U } \\
\text { test }\end{array}$ & HA east & HA west & WA 5 & WA 3 \\
\hline $\mathrm{Cu}(\mu \mathrm{g} / \mathrm{I})$ & $p$-value & $1.32 \mathrm{E}-05$ & $5.48 \mathrm{E}-07$ & 0.001563 & 0.000987 \\
\hline Cu dissolved( $\mu \mathrm{g} / \mathrm{l})$ & $p$-value & $9.45 \mathrm{E}-06$ & $4.92 \mathrm{E}-07$ & 0.007813 & $8.23 \mathrm{E}-05$ \\
\hline $\mathrm{Pb}(\mu \mathrm{g} / \mathrm{I})$ & $p$-value & 0.01699 & 4.04E-06 & 0.5941 & 0.4729 \\
\hline $\mathrm{Pb}$ dissolved $(\mu \mathrm{g} / \mathrm{l})$ & $p$ value & 0.1867 & 0.7822 & 1 & 0.9483 \\
\hline $\mathrm{Zn}(\mu \mathrm{g} / \mathrm{l})$ & $p$-value & $5.25 \mathrm{E}-07$ & - & 0.02076 & 0.01522 \\
\hline Zn dissolved $(\mu \mathrm{g} / \mathrm{l})$ & $p$-value & $1.1 \mathrm{E}-08$ & - & 0.003702 & 0.01058 \\
\hline Ammonia (mg/l) & $p$-value & 0.08938 & 0.06996 & 0.1783 & 0.8659 \\
\hline Nitrate $(\mathrm{mg} / \mathrm{l})$ & $p$-value & 0.04032 & 0.1568 & 0.4262 & 0.9315 \\
\hline o-Phosphate(mg/l) & $p$-value & 3.29E-08 & $9.82 \mathrm{E}-08$ & 0.000839 & 0.000839 \\
\hline $\mathrm{TP}(\mathrm{mg} / \mathrm{l})$ & $p$-value & $6.32 \mathrm{E}-07$ & $1.36 \mathrm{E}-08$ & 0.00057 & 0.001502 \\
\hline TSS (mg/l) & $p$-value & 0.7665 & 0.197 & 0.835 & 0.9587 \\
\hline
\end{tabular}

